\title{
Measuring The Financial Stability of Islamic and Conventional Banks in Turkey
}

\author{
Marei M. Elbadri \\ Submitted to the \\ Institute of Graduate Studies and Research \\ in Partial fulfilment of the Requirements for the Degree of \\ Master of Science \\ in \\ Banking and Finance
}

Eastern Mediterranean University

February 2015

Gazimağusa North Cyprus 
Approval of the Institute of Graduate Studies and Research

Prof. Dr. Serhan Çiftçioğlu Acting Director

I certify that this thesis satisfies the requirements as a thesis for the degree of Master of Science in Banking and Finance.

Assoc Prof. Dr. Nesrin Özataç

Chair, Department of Banking and Finance

We certify that we have read this thesis and that in our opinion it is fully adequate in scope and quality as a thesis for the degree of Master of Science in Banking and Finance.

Assoc. Prof. Dr. Eralp Bektaş

Supervisor

Examining Committee

1. Assoc. Prof. Dr. Eralp Bektaş

2. Assoc. Prof. Dr. Nesrin Özataç

3. Asst. Prof. Dr. Korhan Gökmenoğlu 


\section{ABSTRACT}

The objective of this study is measure and compare the financial stability of Islamic and conventional banks operating in Turkey for the period of 2006 to 2013.The sample consist of twenty four banks, including four Islamic banks and twenty conventional banks. The study focus on three kinds of variables, bank specific, banking sector, and macro- economic. Variables of banks are z-score, total assets, ratio of credits to assets, cost to income ratio, and income diversity. The variables of macroeconomic level are real economic growth and Inflation rate. The variables of the banking sector are Herfindahl index of total assets and share of Islamic banks in the bank sector. The study builds on quantitative tools using panel regression in which the z-score used as a proxy for financial stability. We find that large commercial banks have financial stability, less than small commercial banks, large Islamic banks have financial stability, less than large commercial banks, and large Islamic banks tend to be financially stronger than small Islamic banks. Also, there are a negative relationship between financial stability and the size of the bank. Banks which have high loan to asset ratios moves toward low index of financial stability. Greater operating cost to income ratio have a positive sign, greater operating cost to income ratios lead to deteriorate financial stability index. Income diversity leads to decrease financial stability in banks operating in Turkey. Banks operating in Turkey with higher Islamic bank share have contributed effectively to improve the financial stability through the diversification of their assets. Regarding the macroeconomic variables (GDP, inflation) have significant effects on stability, which explains the importance of financial and economic policies of the government in increase the financial stability of the banks operating in Turkey. 
Keywords: Islamic Banking, Conventioal Banking, Financial Stability. 


\section{ÖZ}

$\mathrm{Bu}$ araştırmanın amacı Türkiye'de işlem yapan İslam ve convensiyonel bankaların 2006-2013 tarihleri arasındaki dönemdeki finasal stabiliteyi karşılaştırmak ve ölçmektir. Çalışma, 4ü İslam bankası ve 20si de convensiyonel banka olup toplam 24 bankadan oluşur. Çalışma üç ana tema üğzerinde durmaktadır; spesifik bankacılık, bankacılık sektörü ve macro-ekonomi. Bankaların verileri ise z-puan, toplam mal, kredilerin mallara göre oranları, gelir oranının pahası ve gelirin çeşitliliğinden oluşmaktadır. Macro-ekonominin verileri ise gerçek ekonomik büyüme ve enflasyon oranından oluşur. Bankacılık sektörünün verileri ise toplam malın Herhindahl indeksi İslam bankalarının bankacılık sektöründeki paydan oluşur. Araştırma, panel regresyonu kullan nicel veriler üzerinden yapılmıştır. Bu nicel veriler ise finansak stabilite için z-puanı proksi olarak kullanmıştır. Araştırma sonucunda ortaya c1kmıştır ki, büyük bankaların küçük bankalara göre finansal stabilitesi daha çok vardır. Büyük İslam bankaları ise küçük İslam bankalarına göre daha güçlüdürler. Finansal stabilite ve bankanın büyüklügü arasında olumsuz bir bağlantı vardır. Mal oranlarının yüksek kredilerini karşılaştıran bankalar daha düşük endeksli finansal stabiliteye doğru ilerlerler. Gelir oranına göre daha fazla olan çalışma oranı olan bankalar, finansal stabiliteye endeksli olumlu bağlantıları vardır. Türkiye'de çalışan bankalardaki gelir çeşitliliği finansal stabilitenin azalmasına yol açmaktadır. Türkiye'de bulunan ve İslam bankalarının paydaşları yüksek olan bankalarda malların çeşitliliği ile finansal stabiliteye katkıda bulunmuşlardır. Makro-ekonomik verilere bakıldığında ise enflasyonun önemli etkileri olduğu görülmektedir ve buda Türkiye'de çalışan bankaların finansal ve ekonomik açıdan prensiplere sahip olmalarının öneminin göstermektedir. 
Anahtar kelimeler: İslam Bankacılığı, Konvensiyonel bankalar, Finansal Stabilite 


\section{DEDICATION}

To loving me to no end.

I Love you Mom

To my mother 


\section{ACKNOWLEDGMENT}

I am most grateful to Allah (swt), for blessing me to complete my thesis in a timely manner. I would like to thank Assoc. Prof. Dr. Eralp Bektas for his continuous support, Motivation, encouragement, guidance, corrections, and advice in the preparation of this study. I would like to thank my family who supported me during my studies. Also, I would like to dedicate this study to them as an indication of their significance in this study. Finally, I offer my regards to all of those who supported me in any aspect through the completion of this thesis, whom I regrettably cannot acknowledge individually by name here. 


\section{TABLE OF CONTENTS}

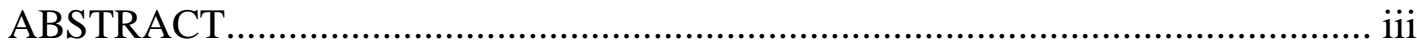

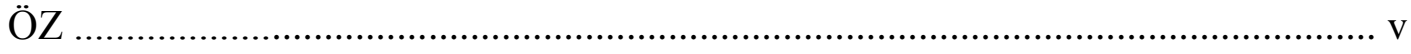

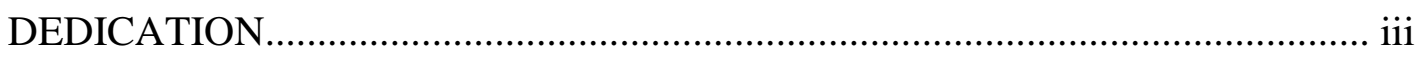

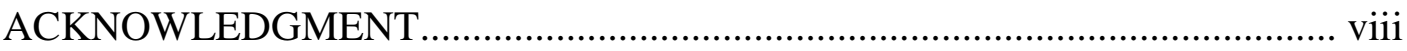

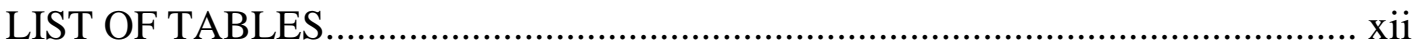

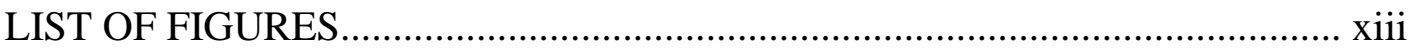

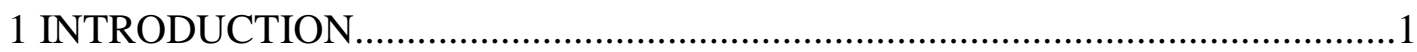

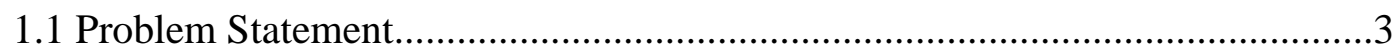

1.2 Aim of The study.....................................................

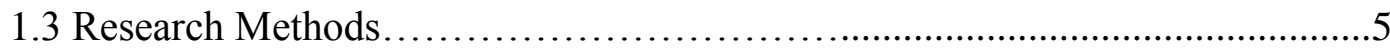

1.4 Significance of The Research............................................... 5

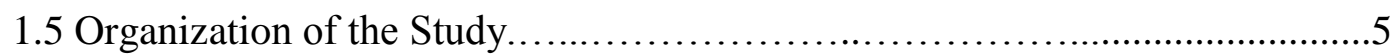

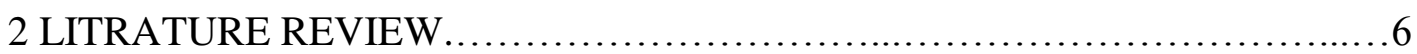

3 BACKGROUND REVIEW ............................................. 14

3.1 The Islamic Banking................................................ 14

3.1.1 The Principles of Islamic finance........................................15

3.1.2 Specific Characteristics of Islamic Banks...............................16

3.1.3 The financial Instruments........................................... 16

3.1.4 Differences between Islamic and Conventional Banks.................18

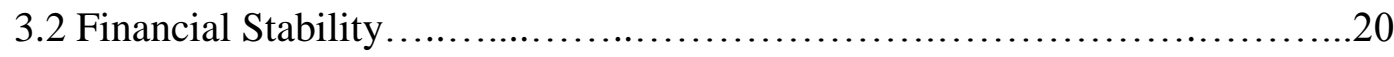

3.3 Nature of bank crises....................................................

3.4 Relationship between the financial crisis and Islamic finance.................23 


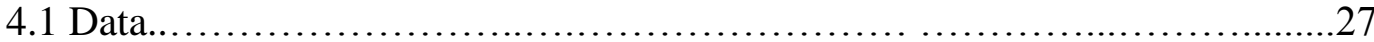

4.2 Methodology........................................................... 27

4.2.1 Measuring Bank Stability.............................................2

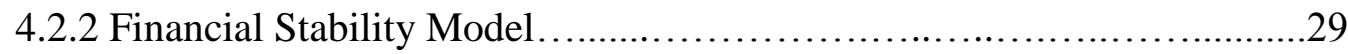

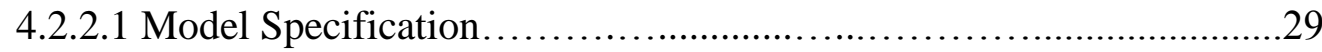

4.2.2.2 Variables of the study.........................................29

A. The Variables of bank specific...................................29

B. The banking sector Variables...................................... 30

C. The macroeconomic variables ....................................31

5 EMBIRICAL RESULTS............................................... 34

5.1 Measuring Bank Stability............................................. 34

5. 2 Regression analysis...................................................... 35

5.2.1 Panel Unit Root Tests.............................................. 35

5.2.2 Hausman Test..................................................... 36

5.2.3 Descriptive Statistics........................................... 36

5.2.4 Correlation Matrix............................................... 38

5.2.5 The regression results..........................................40

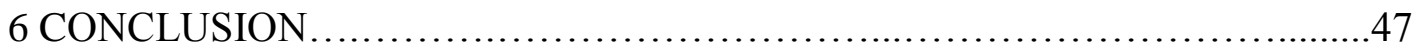

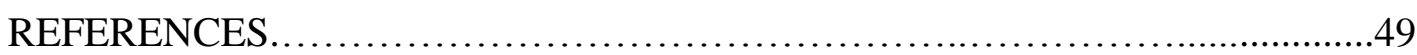

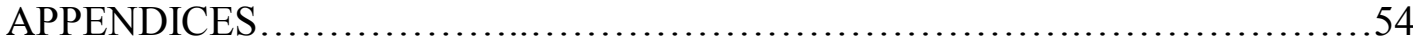

Appendix 1: Unit Root Test for LZ-SCORE...........................55

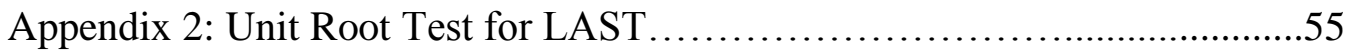

Appendix 3: Unit Root Test for RCA.................................56 
Appendix 4: Unit Root Test for RCI....................................56

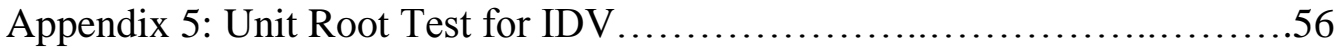

Appendix 6: Unit Root Test for SHIB .................................57

Appendix 7: Unit Root Test for GRW ................................57

Appendix 8: Unit Root Test for INF...................................57

Appendix 9: Hausman Test..........................................58 


\section{LIST OF TABLES}

Table 3.1: Differences between Islamic and conventional banks...................19

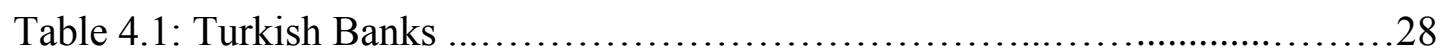

Table 4.2: Studies of Stability measurement.................................... 32

Table 5.1: the Result of Hausman test......................................... 36

Table 5.2: Descriptive Statistics for all Banks..................................37

Table 5.3: Descriptive Statistics of LZ-SCORE for Islamic and Conventional

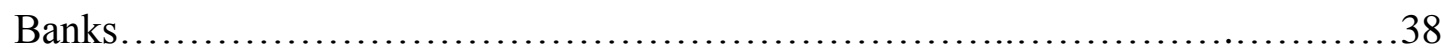

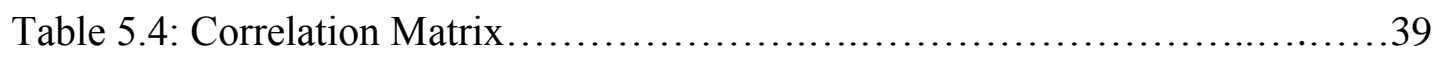

Table 5.5: Regression results - fixed Effects.................................42 


\section{LIST OF FIGURES}

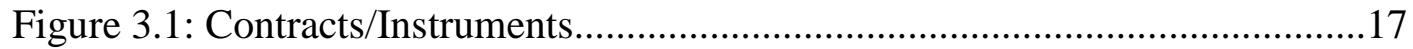

Figure 5.1: Comparison of average Z-scores to the banking sector operating in

Turkey. .35 


\section{Chapter 1}

\section{INTRODUCTION}

Recently, Islamic financial industry is in the focus of consideration in the traditional financial markets. At the same time, Islamic financial industry is a rapidly growing system of the financial world. In fact, Islamic financial industry is widely spread not only within Muslim countries but also to many other countries where there is an Islamic community. According to some statistics, more than two hundred and fifty financial institutions in more than forty five countries exercise some financial activities submissive with Islamic Shariah. Moreover, for the past five years the Islamic financial industry has been increasing greater than $15 \%$ annually. The recent yearly revenue of the market is approximated to be $\$ 350$ million versus $\$ 5$ billion in 1985. A detailed research was conducted in the 1970s which indicated the arrival of the Islamic banking industry. This industry was concentrating mainly on the feasibility and operation of deposit-accepting financial institutions. Yet, these institutions mainly functioned on the basis of profit and loss sharing partnerships instead of the payment or receipt of interest; the reason being Islam prohibits interest in its bylaws (Greuning and Iqbal, 2008).

Islamic banks depend on different business principles such as lender-borrower cooperation instead of no interest, no profit and loss sharing. However, profit and loss sharing principle are applied through different approaches such as Musharakah approach which is used to finance long term projects. The project consists of the 
client contributing some of his own equity capital for investment but the remaining of the equity is provided by the bank Mudaraba. In this situation, all capital required to finance the project is provided by the bank; this is where the client provides his expertise and his labor. Ijara model is similar to the conventional operating lease but without the option of ownership for the client. This pattern of operation assists Islamic banks to be more constant because they persuade investors to expand and increase their profits. Therefore, the investment will raise and competence will advance (Ouerghi, 2014).

The stability of the banking system is regarded as the basis of the stability of whole financial sector where banks play an important role especially in the money creation, financing of investment, economic growth and payment system. Moreover, to conserve economic and financial stability, central banks and other authorized instiuutions have a special interest in evaluating the banking system stability. The banking system stability is usually reflected by advantages such as bank runs or liquidity and following risks concerning to liquidity in the banking sector, which affect their customers and thereby their levels of confidence (Hussein, 2010).

The recent financial crisis has led to re-focus on the relationship between financial reliability and Islamic banks; in particular, on the ability of the Islamic banking system during the period of crisis. In the recent years academics and specialists of Islamic finance industry found the significant growth in Islamic finance. On the other hand, others have justified that the short of revelation to the type of resources are linked with most of the losses. These loses are faced by many traditional banks during the crisis period. The nature of Islamic finance based on the assets and risksharing led to the protection of Islamic banks against the effects of financial crisis. 
Some have justified that Islamic banks resembling conventional banks, adopted on leverage in addition to large risks that make them exposed to the impact of the second global crisis (Hasan and Dridi, 2010).

The Islamic banking industry is a rapidly growing sector in the financial system of the world. In fact, this industry in some countries has become important and in other countries it is largely ignored. There are many factors that have assisted this rapid growth. For instance, strong demand for Shariah-compliant products demand a grow by traditional investors for the purposes of diversification, developments in the framework of Islamic finance, regulatory and legality and the ability of Islamic banks to make several financial instruments that meets the majority of the needs for investors who estimate the indication that the Islamic banks size at the level of the world was about $\$ 820$ billion the end of 2008 (Hasan and Dridi, 2010).

\subsection{Problem Statement}

There has been a number of studies regarding Islamic banking system. The studies which have been carried was for the banking system without interest. It has been seen that there is a vital need to establish the appropriate tools for an early warning system to anticipate bankruptcy especially in an Islamic banking system due to the Islamic banks' nature.

The damage of the financial crisis worldwide is limited for the Islamic banks. But this is not because these constitutions are protected, it is because the Islamic banks competed between capitalized and traditional banks. As a result, the countries which follow the Islamic banking system are not affected by the global financial crisis. Nevertheless, there were a few cases of financial distress of Islamic banks, which 
must be taken into account, and which also led to the conduct of this study. For instance, there was an incident of the Souk Al-Manakh Stock Market (1986-1987) that caused all the banks in Kuwait to become insolvent which was due to the large amount of debt arising from the collapse. There are other examples such as the liquidation of the International Islamic Bank in Denmark in 1986 as result to excessive exposure to finance a single client. Also Islamic investment companies of Egypt in 1988 closed as a result of weak corporate governance and management irresponsibility as well as inappropriate regulatory frameworks in respect to the entry of Shari'ah non-compliant activities. Additionally, the collapse of the Ihlas Finance House in Turkey in 2001 indicated the most serious case of Islamic bank failure. A recent crisis in late 2009 is known as the Dubai Debt Crisis when Dubai World requested a restructuring $\$ 26$ billion in debts which left the world economies shaking. The major concern in this case was the delay in the repayment of a $\$ 4$ billion to Islamic bond or sukuk, which matured on December, 2009 (Othman, 2012).

According to the above discussions, these cases led us to conduct this study to measuring and comparing the financial stability of Islamic and conventional banks operating in Turkey.

\subsection{Aim of The Study}

The primary aim of the study is to measure and compare the stability of the Turkish banks, covering Islamic and conventional banks operating in Turkey, through the use of data from 2006 to 2013, which also covers the global financial crisis shocks (2007-2008). 


\subsection{Research Methods}

We can measure the robustness and stability of the financial system, especially the banking sector by using the Altman (1983) model when z-score is used as a measure.

The study will focus on a three kinds of variables including bank specific, banking sector, and macro-economic level. Variables of banks are z-score, total assets, ratio of credits to assets, cost to income rate and income diversity. The variables of macroeconomic level are real economic growth and inflation rate. The variables of the banking system are Herfindahl index and share of Islamic banks. The study is based on tools of quantities to design the index of z-score and examine the stability of banks in Turkey.

\subsection{Significance of The Research}

The importance of this study stems from the importance of the banking sector, where the banking sector is considered to be one of the most important key sectors in the Turkish economy. This is not only for its important role in the mobilize domestic and foreign savings and finances. But it includes the investment which is the backbone of economic activity. This represents the most important communication tool with the outside financial world.

\subsection{Organization of the Study}

The study is organized as follows: following the introduction in Chapter 1, Chapter 2 discusses literature review, Chapter 3 displays the Background Review, Chapter 4 describes data, methodology and the tools for measuring bank stability, Chapter 5 states empirical results and Chapter 6 gives the conclusion. 


\section{Chapter 2}

\section{LITERATURE REVIEW}

There are a few studies interested to measure and compare the financial stability in the Islamic and conventional banks, especially using quantitative methods and they will be summed up as follows:

Study of Kaleem (2000) attempted to evaluate and develop the demand for instruments compliant with Islamic Sharia, in the case of the dual banking sector. This empirical study aimed to examine the validity of the hypothesis that the financial instruments compliant with Islamic Sharia is as stable as that on the basisinterest. In the case of the dual banking sector operating in Malaysia for the period of 1994 - 1999 to test the performance of the banking system. Pre and post of the financial crisis took place in the years between 1997-1998 and the results indicated that the banking system compliant with Islamic Sharia was more stable compared with the conventional banks operating in Malaysia.

Ali Mirzaei (2010) test the effect of Market Power on the stability of Islamic and conventional banks in the Middle Eastern countries. Used bank-level panel data assesses high returns relatively in the Islamic banking system. The study concluded that the banking system based on Islamic Sharia is biased towards the returns of market power hypothesis. As for the interest rates spreads seems to characterize the traditional system with the trade-off between returns and risk. Profitability was continuous and strong which shows that leaving the competitive structure of the 
market may be important.

Čihák and Hesse (2008) analyze and compare the financial stability between two types of banks which are Islamic and conventional banks, through the use of ZSCORE as an indicator to measure the financial stability. The data is obtained from the Bank Scope with the sample consisting of 20 countries. The study covered the period from 1993 to 2004 . They concluded that the small Islamic banks were more financially strong than small conventional banks, the largest Islamic banks were financially weaker than large conventional banks. Also they found that small Islamic banks are stronger than large Islamic banks. This conclusion may reflect the challenges which large Islamic banks in the management of credit risk face. In addition, it was found that the market share of Islamic banks significantly does not have an effect on the financial strength of the conventional banks.

Iskenderoglu and Tomak (2013) examines the relationship between competition and stability in the Turkish banking sector using quarterly bank level data of 15 private commercial banks, covering the period of 2002-2012. They used Z-index and NPL's (The ratio of nonperforming loans to total loans) as dependent variables to measure for financial stability. As they used fixed assets to total assets and deposits to total assets on bank level, the log value of bank level Total Assets, Herfindahl Hirschman Total Assets index, the Herfindahl - Hirschman Deposit index and Herfindahl - Hirschman Loans indexed as Independent variables. Therefore, their findings did not support well known theories that stand out on the relationship between competition and stability of the banking sector so far. These findings suggest that it is not possible to make any rigorous inference that one view is relevant to the Turkish banking system. 
Rahim and Zakaria (2013) examined and compared financial stability between Islamic banks and conventional banks operating in Malaysia, during the period from 2005 to 2010. The sample of study consisted of 17 Islamic banks and 21 conventional banks by using a panel data analysis. The researchers used both the ZScore and non-performing loans to total loans as a proxy indicator for financial stability. The results indicate that Shariah-compliant banks compared to conventional banks were more stable. Also, the study found that all the factors that affect the stability of Islamic and conventional banks were similar with the exception of income diversity index. This showed the reason during the last financial crisis. At this time, Islamic Banks remained stable compared with the conventional banks while multiple sources of bank income were negatively affected.

Beck et al. (2010) studied bank products compliant with Islamic Sharia versus conventional banking through constructing and comparing indicators of business orientation, efficiency, asset quality and stability of both conventional and Islamic banks. The sample of study consists of the 100 largest banks in terms of assets for 22 countries, for the period from 1995 to 2007 and gets the data from Bankscope. The study found little statistically significant difference between few Shariah-compliant banks and conventional banks. There is a small difference between the two kinds of banks during the financial crisis clear difference in the variation between those banks, across countries and years with different market shares of Islamic banks. Also found in countries that have a larger share of Islamic banks that the conventional banks are less stable but more effective in terms of cost.

Altaee et al. (2013) assess and analyze financial stability for all Islamic and conventional banks operating in Gulf Cooperation Council (GCC) countries, for the 
period from 2010 to 2013 and this period is divided into two groups, the first covering the pre-financial crisis and the second post financial crisis. The study used the Z-core as a proxy for measuring financial stability. In addition, macro and microeconomic factors used as independent variables to measure their impact on financial stability. The micro-economic independent variables are total assets, loans/total assets, cost ratio, income diversity ratio, dummy variable of the bank and market share in the country; while the macroeconomic independent variables are consumer price index, governance and gross domestic product (GDP) growth. The study found that there is no significant difference between the financial stability of Shariah-compliant banks and conventional banks during the periods, before and after the financial crisis. Also the conventional banks usually tend to be stronger than Islamic banks for the period before the crisis.

Samad and Hassan (1999) measured and compared the performance of Islamic banks to conventional banks operating in Malaysia, during the period from 1984 to 1997. The study which was exploratory, aimed to evaluate intertemporal and interbank performance between the banks and the Berhad Islamic Bank in profitability, liquidity, risk, and solvency. The study found through comparison that the Islamic Bank (Berhad) is more liquid and less risky from conventional banks. In addition, this study identified the reason behind the idea that sharia-compliant banks are not popular in Malaysia. The study indicated that the most important reason is the lack of professional bankers with knowledge in evaluating and selecting and managing profitable projects.

Hasan and Dridi (2010) examine the effects of the global financial crisis that occurred recently in the Islamic and conventional banks in particular during the 
period from 2007 to 2008. In many countries conventional and Islamic banks are operating together, namely Saudi Arabia, Jordan, Qatar, Kuwait, Bahrain, Malaysia, Turkey, and UAE. A sample of 120 banks has been studied, including $25 \%$ were Islamic banks. The study was done by considering the impact of the financial crisis on credit and asset growth, profitability, and external classifications in a set of countries where a conventional and islamic banks have significant share of market. They found that the impact of the recent global crisis was different between the two types of banks. For example, it is found that the business model of Islamic banks is considered as one of the factors that helped in reducing the negative impact of the crisis on profitability. In 2009 risk management practices led to decline profitability of Islamic banks compared to conventional banks. The performance of Islamic banks are better than conventional banks in terms of credit and asset growth during the years from 2008-2009, respectively. Regarding credit and an asset growth, performance of Islamic banks were better than conventional banks in the years 20082009, respectively, and supporting economic and financial stability.

Ghassan and Taher, (2013) measured the financial stability of bank sector in Saudi Arabia, Islamic and conventional banks, through the quarterly data which extends from 2005 to 2009. They used a sample which consisted of 2 Islamic banks and 4 conventional banks, which represented about $64 \%$ of the banks that are operating in the Saudi capital market. The study relied on the Z-Score as the dependent variable to see the stability of the banking sector. In addition, the three types of independent variables are bank specific, banking sector and macroeconomic variables. By using panel and pooled regressions they found that Islamic banks relatively reduced financial stability index, but at the same time contributed effectively in promoting financial stability through diversification of their financial instruments. In terms of 
the competitiveness of the banking sector in Saudi Arabia, it has a negative impact on financial stability. This may be due to the small number of Islamic banks which are operating in Saudi Arabia and may reflect negatively on improving financial stability.

In order to obtain additional information to help understand and configure the background on the relationship between Islamic banks and conventional banks, in terms of performance, competition, profitability, the effects of the financial crisis, global expansion, the researcher presented some literature review following for this purpose.

The study of Ariss (2010) analyzes competitiveness conditions of the Islamic banks compared to conventional banks, and detect potential differences between these markets. The study included several banks in 13 countries during the period from 2000 to 2006 through many indicators like PR H-statistic ${ }^{1}$ index and market power index for banks (Lerner index). The findings indicate that Shariah-compliant banks allocated large share of its assets in financing activities compared with conventional banks, and also Islamic banks less competitive than conventional banks. Profitability increases significantly with the market power, but this does not justify the high profitability of Shariah-compliant banks.

Imam and Kpodar (2010) studied the several factors that affect the growth of the global market to Shariah-compliant banks using county-level data for 1992 to 2006. They used many of the factors that affect the global expansion of Islamic finance, for instance ratio the Muslim population in the countries, domestic financial system

\footnotetext{
${ }^{1}$ the methodology of Panzar and Rosse (1987), the so-called H-statistic, used to assess competitive conduct.
} 
technology, the real interest rate, the average per capita income, the events of September 11, the degree of integration of the Middle East and oil prices. The findings explained that ratio of the Muslim population in the country, average per capita income and oil prices are associated with the Islamic banking development, as are economic integration with countries in the Middle East. Also rates of interest have negative effect on Islamic banking, which reflected implicitly the benchmark for these banks. The institution's quality does not matter. The September 11 attacks were not important. Prices of oil also are an important factor in the spread of Islamic banking. Islamic banks also seems to be complementary to conventional banks, but are not the alternative.

Javid et al (2011) studied the factors that determine the profitability of the Pakistani banks, through Internal Factor Analysis. This study was aimed to analyze the determinants of profitability of the large 10 banks operating in Pakistan, through the concentration only on the internal factors, during the period 2004-2008. They used method of ordinary Least Squares to reveal the impact of assets, equity, deposits, and loans on one of the main profitability index return relative to asset. The findings indicate the presence of strong evidence that these variables have a strong impact on profitability.

Study by Ariff et al (2008) measures and compares the cost, revenue and profit efficiency of 43 Islamic and 37 conventional banks in 21 countries, the data in this study were collected between 1990 and 2005, and used Data Envelopment Analysis. This study aims to demonstrate how the Islamic banking sector reacted during the 1990 financial crisis. And past trends that could be used to extrapolate likely future behavior for both banking systems. The results indicate with respect to the creation 
of the profits that Islamic banks and Western were equally efficiently with the use of resources commensurate with their abilities. Regarding the efficiency of the performance, small Islamic banks were more efficient than conventional banks, due to their respective capital structure. Also due to that smaller conventional banks which were in greater competition there are negative consequences on their revenue. Also identified that both smaller and larger Islamic banks needed to pay more attention to cost and profit efficiency if they want maintain competitiveness. Lastly, Regarding bank efficiency and its relationship to geographical area, indicated in Africa, Western banks outperform, in Asia Islamic banking performed better than Western banking in cost, revenue, and profits in Turkey and the Middle East.

Bashir (2001) performs regression analyses to consider the determinants of Islamic banks' performance during the period from 1993 to 1998 in eight Middle Eastern countries. And used a variety of characteristics of internal and external banking to forecasting profitability and efficiency. Broadly, his results show and confirm controlling for macroeconomic environment, taxation, and financial market structure, the finding indicates that high profitability comes from high leverage and large loans to asset ratios. The results also indicate that foreign-owned banks are more profitable than their domestic counterparts. Everything remaining equal, there is evidence that implicit and explicit taxes affect the bank performance measures negatively. Furthermore, appropriate macro-economic circumstances positively affect the performance indicators. Findings also indicate that stock markets are a complement to bank financing. 


\section{Chapter 3}

\section{BACKGROUND REVIEW}

As we know that this study is Interested by measuring and compare the financial stability in the banks operating in Turkey, especially Islamic and conventional banks. As a precondition, in this chapter, it is necessary to determine the specific characteristics of sharia-compliant banks and their consequences in terms of risk, the difference between the two types of these banks, explain the concept of financial stability, nature of bank crises, and the relationship between the financial crisis and Islamic finance.

\subsection{The Islamic Banking}

The basic principle of sharia-compliant banks are to achieve social and economic justice instead of principle of profit maximization, this can be essentially achieved through encouraging techniques of risk-sharing financing (Turk, 2010).

The sharia-compliant banks defined as banking services that consistent with the value and ethos of Islamic system, rules of risk management, and the traditional good governance, through the foundations or principles established by Sharia. Interest-free banking is considered an incomplete term indicates many of the instruments or the operations of banks which do not use interest term. Sharia-compliant banks are the most general concept, it is not only to avoid unethical transactions or prohibit interest-based transactions, and also actively participate towards the objectives and purposes of an Islamic economy (Moin 2013). Islamic banks are working like 
commercial banks and investment intermediaries together which means this bank is accepted for two types of deposits from the public, current accounts and investment accounts, which form the basis for two theoretical banking models. The two-level Mudharabah model is in its balance sheet liabilities and balance sheet assets. First level the bank enters into an unlimited Mudarabah contract between itself and the holders of investment accounts. This contract is unlimited in the sense that the bank's management has total discretion to invest this money in what it considers to be the most profitable Sharia compliant projects. The second level, funds are invested by way of limited Murabaha contracts; the limitation lies in the choice of projects and those undertaking them. The bank also receives current account deposits. Although the full amount of such deposits is guaranteed and available at all times, current account depositors are aware that their deposits are used for risky projects. However, they do not receive any interest on their deposits. Furthermore, a portion of these deposits is used for interest-free loans. This type of loan forms part of the bank's social activities. There is no requirement to hold reserves under this model (Boumediene, 2009).

\subsubsection{The Principles of Islamic Finance}

There are many of the basic principles in which through it operating Islamic banks, include the following (Said 2008):

1. Prevent paying or receipting interest.

2. Each economic activity is permitted unless expressly prohibited by Islamic Sharia, which includes commands contained in the Quran or derived from the Sunnah.

3. In any process should be shared the risks between the two parties, between the provider and the entrepreneur money, in return for a share of the profits.

4. Money can considered as actual capital only if it is used in a capacity of 
production, or along with labor. Otherwise considered as potential capital.

5. Contractual commitments and disclosure of information are necessary. This means speculative behavior or extreme uncertainty and risk are prohibited.

\subsubsection{Specific Characteristics of Islamic Banks}

The most important characteristics that are unique to Islamic banks is the prohibition against paying and receipt interest at a fixed rate or predetermined. Instead, the bank financial services are based on agreements, sharing profits and losses through the purchase of goods and services, and then re-sell them and provision of services in exchange the fees that are the basis for contracts of Islamic finance. In the Islamic finance model represented in profit and loss sharing mode. In addition, the returns on assets is not fixed or known before completion of the transaction. In these transactions, which is based on the purchase - resale, are determined based on a Standard rate of returns, and the returns is determined based on global markets such as the LIBOR (London Interbank Offered Rate). There is a set of Islamic financing contract states that the right of an investor manages the project and determine the timing of cash flows. In addition, there is another feature of banks that operate according to Islamic Sharia are generally prohibited from dealing with financial risks, which in nature are similar to Gambling. And financing trade or produce commodities that are not correspond with Islamic sharia, such as alcoholic drinks and pork, etc. (Čihák And Hesse, 2008)

\subsubsection{The Financial Instrument}

Economic system compatible with Islamic sharia can be classified into four main categories, which represent a set of basic contracts (Iqbal and Mirakhor, 2011), as shown in Figure 3.1. 


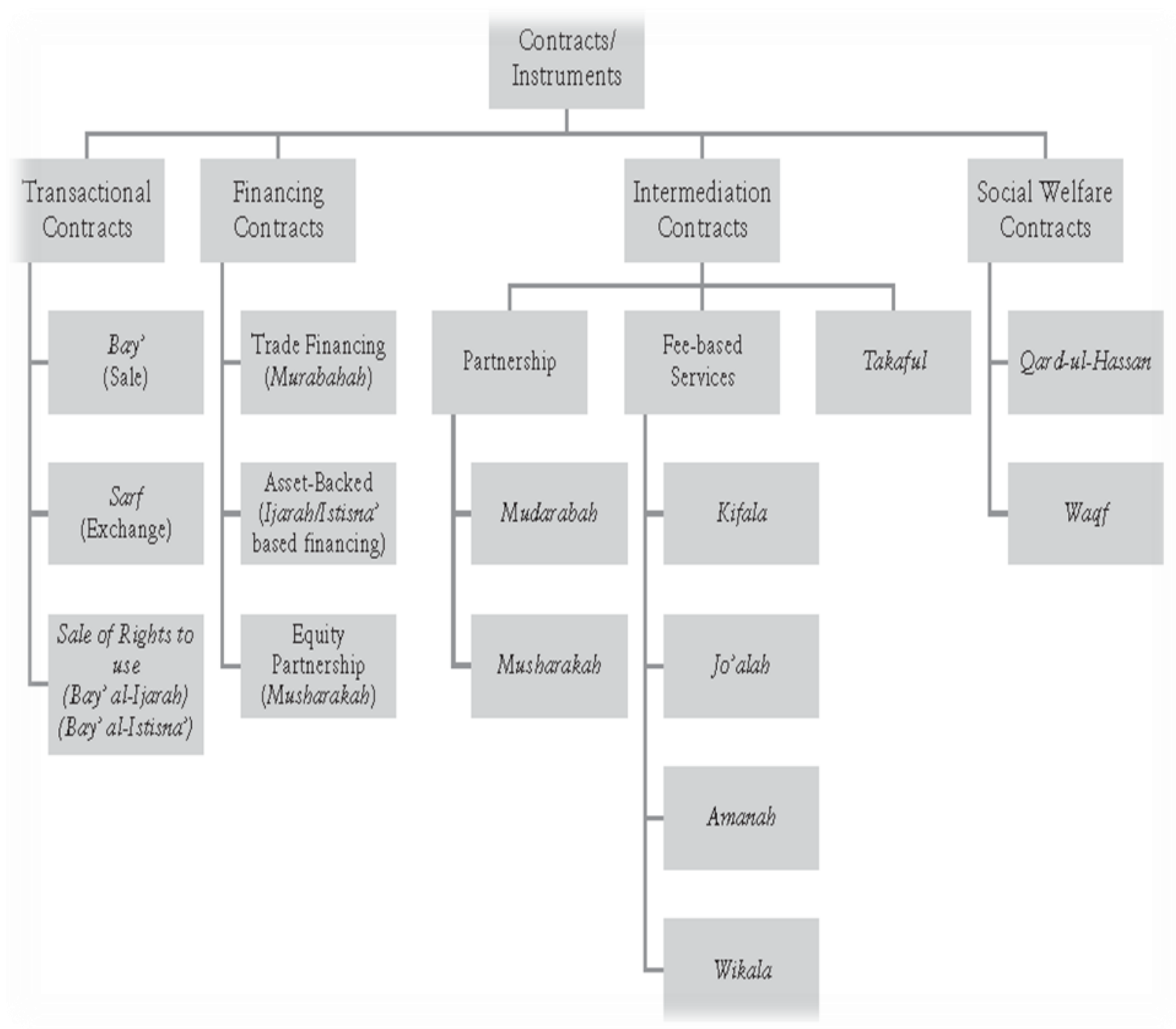

Figure 3.1: Contracts/Instruments

This classification that is described by drawing is based on the function and purpose of the contract, making it easier for us to understand the nature and function of money creation, In addition to finance instruments, its types, and its role in the Islamic economic system. In terms of commercial law of Islam will be able to address all the requirements needed for the economic agents by different stages of economic activities, The right to buy and sell the goods, arrangements for the procedures of guarantees, or credit or finance, and lastly to create the investment opportunities. Where the contracts of transactions deal with the real - sector economic transactions for purpose facilitating sale the goods and exchange the 
services. Financing contracts provide the means to create credit, and to facilitate the financing of transactions and contracts, and provide channels for capital formation and the transfer of resources among entrepreneurs and investors. The contracts of intermediation plays a role in facilitating the efficiency and transparency in the execution of transactions and financial contracts, and also provide agents of an economy with a group of tools to conduct mediation and provide fee - existing services on economic activities. Lastly, Social-welfare contracts are aimed to enhance the welfare of the poor, usually contracts are between individuals and society. Use of sharia-compliant banks these types of financial instruments ultimately lead to support stability of financial and the banking system, which allows banks to diversify their investments, thereby reducing the risks and increase their profits. Accordingly, these financial instruments attract more investors, which makes Islamic banks operate more efficiently (Ali Said, 2012).

\subsubsection{Differences Between Islamic and Conventional Banks}

As we know that the main aim of our study is to measure and compare the financial stability of the sharia-compliant banks and conventional banks operating in Turkey, this requires knowledge of the difference between the two types of banks, according to the structure of assets on its balance sheet. Islamic banks firstly has relied on single layer Mudarabah, through directly mobilization of liabilities in opportunities of different investment. However, this model may be exposed to many operating risks. Thus, Islamic banking system has turned to the use of multilayer Mudarabah Islamic model, in other words, using Mudarabah of assets and liabilities or sources and uses of money together. Through Profit-Loss Sharing system all assets or sources of money are financed (Ghassan and Taher, 2013). But for the shortcut and increase the benefit of the readers to understand the difference between the sharia- 
compliant banks and the conventional banks, we summarize it in the table3.1 (Ust

Hj Zaharuddin, 2007).

Table 3.1: Differences between Islamic and conventional banks

\begin{tabular}{|c|c|}
\hline Islamic Banks & Conventional Banks \\
\hline $\begin{array}{l}\text { 1. The functions and operating modes of } \\
\text { Islamic banks are based on the principles of } \\
\text { Islamic Shariah. }\end{array}$ & $\begin{array}{l}\text { 1. The functions and operating modes of } \\
\text { conventional banks are based on fully } \\
\text { manmade principles. }\end{array}$ \\
\hline $\begin{array}{l}\text { 2. In contrast, it promotes risk sharing between } \\
\text { a provider of capital (investor) and the use of } \\
\text { funds (entrepreneur). }\end{array}$ & $\begin{array}{l}\text { 2. The investor is assured of a predetermined } \\
\text { rate of interest. }\end{array}$ \\
\hline $\begin{array}{l}\text { 3. It also aims at maximizing profit, but subject } \\
\text { to Shariah restrictions. }\end{array}$ & $\begin{array}{l}\text { 3. It aims at maximizing profit without any } \\
\text { restriction. }\end{array}$ \\
\hline $\begin{array}{l}\text { 4. In the system of modern Islamic banking, } \\
\text { Become one of the service-oriented tasks of the } \\
\text { these banks in order to be a Centre of Zakat } \\
\text { aggregation and they also pay out their Zakat. }\end{array}$ & 4. It does not deal with Zakat. \\
\hline $\begin{array}{l}\text { 5. Fundamental function is Participation in } \\
\text { partnership business. So we must understand } \\
\text { our clients very well }\end{array}$ & $\begin{array}{l}\text { 5. Fundamental function is Lending money and } \\
\text { getting it back with compounding interest. }\end{array}$ \\
\hline $\begin{array}{l}\text { 6. Islamic banks do not request to pay any extra } \\
\text { money from the defaulters. Only a small } \\
\text { amount of compensation awarded to charities. } \\
\text { In addition, when the early repayment are giving } \\
\text { discounts according to the discretion of the banks }\end{array}$ & $\begin{array}{l}\text { 6. It can charge additional money (penalty and } \\
\text { compounded interest) in case of the defaulters. }\end{array}$ \\
\hline $\begin{array}{l}\text { 7. A first consideration to the public interest. } \\
\text { Its final goal is to ensure growth with equity. }\end{array}$ & $\begin{array}{l}\text { 7. A first consideration to bank's own interest. } \\
\text { In order to ensure growth with equity. }\end{array}$ \\
\hline $\begin{array}{l}\text { 8. For the Islamic banks, it must be based on a } \\
\text { Shariah approved underlying transaction. }\end{array}$ & $\begin{array}{l}\text { 8. For interest-based commercial banks, } \\
\text { borrowing from the money market is easiest. }\end{array}$ \\
\hline $\begin{array}{l}\text { 9. Since it profits or loss of shares, the Islamic } \\
\text { banks gives greater importance to the } \\
\text { development of project evaluations. }\end{array}$ & $\begin{array}{l}\text { 9. Since income is fixed, it gives little attention } \\
\text { to the development of project evaluations. }\end{array}$ \\
\hline $\begin{array}{l}\text { 10. It give greater focus on the feasibility of the } \\
\text { projects }\end{array}$ & $\begin{array}{l}\text { 10. It gives greater focus on creditworthiness of } \\
\text { the clients. }\end{array}$ \\
\hline $\begin{array}{l}\text { 11. The status of Islamic banks in relation to its } \\
\text { clients is that of partners, investors and trader, } \\
\text { buyer and seller. }\end{array}$ & $\begin{array}{l}\text { 11. The status of a conventional bank, in } \\
\text { relation to its clients, is that of creditor and } \\
\text { debtors. }\end{array}$ \\
\hline $\begin{array}{l}\text { 12. This bank can only ensuring deposits for } \\
\text { accounts of deposit, which is based on the al- } \\
\text { wadiah principle, so the depositors are ensured } \\
\text { repayment of their funds, however if the } \\
\text { account is based on the mudharabah principle, } \\
\text { client have to share in a loss position.. }\end{array}$ & 12. This bank is ensuring all its deposits.. \\
\hline
\end{tabular}




\subsection{Financial Stability}

Financial stability can be defined as the condition where the financial system is able to direct capital to its most profitable investment opportunities without major disturbances. In other words, the financial system is stable if it is capable of absorbing shocks without disruptions to the financial intermediation process. Otherwise, it can collapse, with a related detrimental impact on the real economy. It follows that the financial system does not meet the stability definition when it is stable but does not have the capability of efficiently allocating capital (Babecky el tie, 2010).

Financial stability also is a situation where the financial system is able to allocation of resources efficiently between businesses with the passage of time, assess and manage financial risk, and accommodate shocks. Here, we must distinguish between financial stability and the stability of the banking system, which is the oldest concept for central banks, and is the main reason to establish the Federal Reserve in the United States. With regard to financial stability is associated with the financial system as a whole, which covers the banking, capital markets, foreign exchange, and debt (Boumediene and Caby, 2009). In order to study the financial stability of banking sector, we need to distinguish between types of banks, and depending on the structure of its assets in the balance sheet. The first stage, Islamic banks used Mudarabah of single layer, that mean they crowd directly liabilities to opportunities of different investment. Due to operational risk faced by this model, Islamic banks have been forced to shift to use a Murabaha Islamic model of multilayer, that mean Mudarabah of assets and liabilities, where all assets are financed by the PLS system (Ghassan and Taher, 2013). There is an built-in property in Islamic banks, a strong 
relationship between productivity and financial flows, this feature makes Islamic banks in isolation of the risks that can arise from excessive leverage and speculative financial activities, which are the basic cause of the current crises (Ahmed, 2010).

\subsection{Nature of bank crises}

Financial stability is closely interconnected with monetary stability. Traditionally, a clear distinction is made between these two kinds of stability. Financial stability characterizes the smooth flow of funds between lenders and borrowers and returns on investments with time and risk considerations. Monetary stability characterizes the ability to preserve a stable level of prices for goods and services and to keep acceptable levels of currency fluctuations versus other national currencies. There is a sense of such distinction, grounded by different basic motives (transaction and speculative) driving money and financial markets (Dobravolskas and Seiranov, 2011).

The main reason behind developing a system of an early warning to predict the occurrence of future financial crises was the financial crisis that occurred during 1990s, especially in East Asia and Latin America, which has forced international organizations to pay more attention to identify factors or reasons that leading to the occurrence of such financial crises (Ghassan and Taher, 2013). Despite the fact that for each financial crisis has its reasons, these reasons may be internal or external. The first reason is insufficient market discipline in the financial sector due to the lack of a system sharing profits - losses. The second is the stunning expansion in the magnitude of derivatives, especially credit default swaps, and the third is the "too big to fail" concept, which tends to grant a guarantees to large banks, the central bank plays the role of savior does not allow these banks to fail (Ahmed, 2010). The 
presence of one or more factors listed above strengthens the probability of a financial crisis in the banking system. Consequently the economic sector will be unable to accommodate this crisis resulting from the instability of exchange rates, interest rates, prices. It can be hard to resist the credit and liquidity shocks and other shocks associated with the structure of the nascent institutions because of Re-evaluation of their assets, and change in the demand of financial assets or in the organizational structure. To anticipate these future financial shocks developed financial indicators operate as an early warning devices. For the purpose of modifying its inverse economic and financial effects. The financial crisis may be as a result of an exchange rate crisis, which results in a great loss of the international reserves of the country, especially due to the devaluation of local currency. Maybe the financial crisis due to the failure of the bank, therefore the central bank should intervene to restructure the banking system and provide the banks with reserves. And sometimes financial crises occur as a result of failure of the debt, when the banks thought that defaults become a specific event, or when debtors default on bank loans. These difficulties lead to take the credit rationing plan, which result in depriving the economy from issuing new loans, and must settle outstanding old debts. Sometimes the financial crisis may be the result of government's failure to repay the public debt, which raises investment risk causing a crisis in the exchange rate, and deprived the economy of flow of foreign capitals. Under this uncertainty, banks are raising the interest rates of loans through the addition some risk recompense as an insurance premium, thus risky investor willing to get such loans because of the high expected rate of return on their projects. By contrast, the projects, maybe turn to infeasible as a result of the moderate returns and lower risk, and high financing costs. Therefore turn to banks to finance risky projects, which threaten the financial stability of the banking system, 
this known as adverse selection. Moral hazard may occur due to the asymmetry of information between investors and banks, the investor may use the money obtained through the contract with the bank in a high-risk projects and not agreed upon in the contract, thus considered as a violation of the contract, which raises the risk of the banks, causing the rise in interest rates, a bad selection by the bank, and ultimately result in a negative impact on the performance of the economy (Ghassan and Farid, 2013).

Factors violating stability of the financial system can be divided into two large groups of external (exogenous) and internal (endogenous) factors. The first group of factors unites various macroeconomic disproportions in production and consumption, saving and investment processes, in which global impacts become more and more important. Factors united in the second group arise from imperfect nature of financial markets (Dobravolskas and Seiranov, 2011).

\subsection{Relationship between the financial crisis and Islamic finance}

The most important reason underlying every financial crisis was the result of excessive and non-wise lending from banks during a long time period. Which raises the question, what makes banks resort to such unhealthy and incorrect practices, which destabilize the financial system and harm their interest in long-term (Ahmed, 2010). The main reasons are the asymmetry of information for market participants. Excessive volatility in macroeconomic, for example, fluctuations in global interest rates, term of trade changes, changes in exchange rates, the massive expansion in granting bank credit, incentives to the flow of money followed by a surprise collapse in the prices of asset, which leads to a mismatch among the maturity of assets and liabilities for the banks. In addition, growth of the money supply at a faster rate than 
Gross domestic product (GDP). Moreover, the massive intervention of government in the regulation of banks, and the absence of effective control early, weak legal and accounting systems for the banking sector. Sometimes financial crisis may be caused by a change of exchange rates through the purchase and sale of foreign currencies, or the occurrence of unexpected deterioration in value of real and financial assets of the bank. Such a case, central banks play a role to rescue the bankrupt bank, and thus prevent the occurrence of a banking crisis. (Ghassan and Taher, 2013)

The subprime mortgage crisis in the USA is a classic example of excessive and unwise lending. Securitization or the financing model has a critical role in that. The CDOs creation through mixing prime and subprime debt allowed for the originators of mortgage to pass all the default risk of even subprime debt to the final purchasers who would have been reluctant to talk like this the risk. Originators of mortgage had, thus, less incentive to undertake careful underwriting Consequently, loan volume gained greater priority over loan quality and the lending amount to subprime borrowers and speculators increased deeply. As well, the practices of the unfair lending may force borrowers into mortgages without choosing intentionally. Regarding market discipline may be used for the serving of self-interest. In addition, the supervisors failed to implement effectively their task (Ahmed, 2010). Ultimately, a number of banks either failed or nationalized by the governments in the united states, the united kingdom, Europe, and other places. This led to uncertainty in the market and the credit crisis for a long time, and has become difficult to find sources of funding for banks. There are concerns that this might be only few of the many and a lot may follow if the financial crisis leads to a recession and causes to defaults on the part of credit card institutions, corporations, and derivatives traders While there is an imprudent and excessive lending and lender are unsure of repayment, there is an 
overload resort to derivatives like Credit Default Swaps in order to protection of defaults. The buyer of the swap pays a premium to the seller for the compensation he will receive in the event the debtor default. A large number of other buyers who were willing to bet on the default of the debtor and lending banks bought the hedge funds. Thus this selling process continued. One of the important goals of Islam is to achieve greater justice in human society. Justice requires a set of rules or moral values (Said, 2012).

The financial sector may be capable of achieving justice if meets at least two requisites of moral values. The first is that the financier must participate with the entrepreneur in the risks, so as not to become the whole burden of loss on the entrepreneur, through the participation of the entrepreneur and the financier to fairly participate in the profit and the loss. This would assist introduce the greater discipline to the financial sector, reducing excessive lending. The second is that a fair share of financial resources massed by institutions of financing must be accessible to the poor, to assist reduce inequality of income and wealth. Islamic finance should assist increase significantly the share of equity and profit-loss sharing in business. The system of Islamic finance does not allowed the debt creation by direct borrowing and lending instead requires the debt creation by the lease or sale of real assets using its lease - and sales-based modes of financing (murabaha, Salam, ijara, istisna, and sukuk). The Objective is to empower individuals and companies to buy now the urgently needed real goods and services in consistent with their ability to make the payment At a later time, with a number of conditions, For example, the asset that is will be leased or sold must be real, not Fictitious or notional, the lessor or seller must possess and own the goods being leased or sold. The transaction must be a real trade with the entire intention of giving and taking delivery, and the debt 
cannot be sold and therefore the risks related to it must be borne by the lender himself (Adel Ahmed, 2010). 


\section{Chapter 4}

\section{DATA AND METHODOLOGY}

\subsection{Data}

The Turkish banking system consists of a set of banks, there are two distinguished types, conventional and Islamic banks. Thus, this study used a sample of the available data in order to examine and measure the financial stability of the banking sector operating in Turkey. The bank-level financial data on Islamic and commercial banks for the years 2006-2013 gathered from two sources. The first with respect to Islamic banks is an association of participation banks operating in Turkey and the second with respect to commercial banks which are the banks in association operating in Turkey while utilizing higher quality data hand-collected by the author. The number of banks both Islamic and Conventional are 24. Number of observations are almost 192. Banks which are studied are illustrated below in Table 4.1.

\subsection{Methodology}

\subsubsection{Measuring Bank Stability}

There are many methods generally accepted and used to measure the stability of the financial system in general and the banking sector in particular. Altman model or z-score model are considered as the best among other methods. They are characterized by its ability to predict the possibilities of bank insolvency in the future, while other methods merely knowing what if the bank may face a problem of liquidity. It is based on the historical accounting data extracted from the banks financial statements. It is a combination of capital adequacy, profitability and 
volatility measures. The z-score index can be calculated as follows:

$$
\mathrm{z}=(\mathrm{k}+\mu) / \sigma
$$

Where, $\mathrm{k}$ is the ratio of equity capital and reserves to total assets. $\mu$ represents average net income as a percent of assets, and $\sigma$ is the standard deviation of return on assets (average net income as a present of assets), and measures the return volatility on assets. A higher z-score indicates a lower default risk and vice versa. A higher $\sigma$ indicates the instability of a bank's income that lowers its z-score.

Table 4.1: Turkish Banks

\begin{tabular}{|c|l|l|}
\hline NO & \multicolumn{1}{|c|}{ Banks } & Groups \\
\hline 1 & TÜRKIYE FINANS & Islamic Bank \\
2 & BANK ASYA & \\
3 & KUVEYT TÜRK & \\
4 & ALBARAKA TÜRK ISLAMIC BANKS & \\
\hline 5 & ING Bank A.Ş. & \\
6 & Finans Bank A.Ş. & Foreign Bank \\
7 & HSSBC Bank A.Ş. & \\
8 & Alternatifbank A.Ş. & \\
9 & Turkland Bank A.Ş. & \\
10 & Arap Türk Bankası A.Ş. & \\
11 & Fortis Bank A.Ş. & \\
\hline 12 & Türkiye İş Bankası A.Ş. & \\
13 & Türkiye Garanti Bankası A.Ş. & State-owned Deposit B. \\
14 & Akbank T.A.Ş. & \\
15 & Yapı ve Kredi Bankası A.Ş. & \\
16 & Türk Ekonomi Bankası A.Ş. & \\
17 & Şekerbank T.A.Ş. & \\
18 & Tekstil Bankası A.Ş. & \\
19 & Turkish Bank A.Ş. & \\
20 & Adabank A.Ş. & \\
\hline 21 & Türkiye Cumhuriyeti Ziraat Bankası A.Ş. & \\
22 & Türkiye Halk Bankası A.Ş. & \\
23 & Türkiye Vakıflar Bankası T.A.O. \\
\hline 24 & Birleşik Fon Bankası A.Ş. & \\
\hline
\end{tabular}




\section{2 .2 Financial Stability Model}

At this stage we turn to regression analysis in order to separate the impact of financial stability of the Islamic nature of a bank from other impacts. In addition, to conduct the empirical analysis the panel data have been used. Panel regression deals with multi-dimensional data that contained observations of measurements obtained over multiple time periods for the same firms. Also to know whether all variables are stationary, we conduct tests on panel data, this test is a Fisher- type unit-root test. We have also prepared descriptive statistics and the correlation matrix to know whether the multicollinearity is a problem. In the end, we analyzed with making some models by useing fixed effect for the omitted variables, which may be correlated with other independent variables, and random effect regression for the variables are not omitted, which are not correlated with other independent variables, and make them unbiased.

\subsubsection{Model Specification}

We formulate or estimate a general class of Panel data model as follows

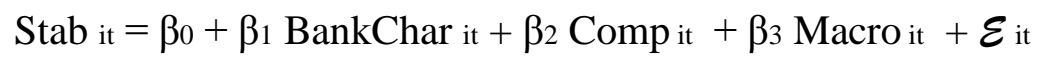

Where Stab stands for the bank stability measure. BankChar is stands for bank specific indicators. Comp is the competition measure. Macro denotes macroeconomic indicators, and The term crefers to the unobserved stochastic errors .

\subsubsection{Variables of the study}

The index of financial stability influenced by a three groups of variables related to bank specific, banking sector and macro-economic.

\section{A. The variables of bank specific}

1. The z-score or bank's stability index, which is used for forecasting financial distress. And indicate to the probability of insolvency. The higher value of z-index 
denotes a higher bank stability and less overall bank risk.

2. Total assets (LAST), we using the log of total assets to control for bank size. financial stability moving to increase with bank size for large banks, as result to a scale economies, but decrease in size for smaller banks. Also larger banks are expected to be less risky because of the increased ability to diversify their sources of income, in all spectrums including geographic, customer and industry.

3. Ratio of credits of assets (RCA) for conventional banks, ratio of financial activity of assets for Islamic banks. Banks with higher ratios of loan to asset expected to have lower financial stability.

4. Ratio of operating costs to income (RCI). This ratio is used as a measure shows how banks manage their total costs relative to their income, the higher this ratio refers the inefficiency. Whenever the ratio was high, this lead to deteriorate financial stability index.

5. Income diversity (IDV), here is positive relationship, the greater the income diversity index, this indicates that the greater support to the financial stability in the banking system.

6. Bank dummy variable, in order to catch the effect of a specific bank on financial stability, there are two dummy variables, one for Islamic banks (IBD), the other for conventional banks (CBD). If the bank is an Islamic bank, a bank dummy variable takes the value of 1 , and 0 if it is a commercial bank. It is used in order separating the effect of bank type on financial stability, this variable take a negative sign in the regression interpreting financial stability, if Islamic banks are weaker than commercial banks.

\section{B. The banking sector variables}

1. Herfindahl-Hirschman Index (HHIA), defined as the sum of squared market shares of all banks in the country. Measured in terms of total assets with Herfindahl - 
Hirschman Total Assets index, which measures the competition in bank sector. This index ranges between zero and 10000 for highly competitive and a least competitive market respectively. The higher $\mathrm{HHI}$ indicates, that mean higher degree of competition, Higher competition to be associated with higher stability. In other words, if this index has a negative sign, this means that the banking system suffer a weak competition, which in turn reflects on the financial stability.

2. The share of Islamic banks (SHIB). We calculate the market share of Islamic banks yearly through assets (Total assets of Islamic banks / The total bank assets). This ratio used to test the impact of Islamic banks on the rest of the banking sector and the hypothesis that the presence of Islamic banks reduces the systemic financial stability. A negative sign for the interaction of the Islamic banks' market share and the Islamic bank dummy would indicate that a higher share of Islamic banks reduces their soundness, which means reduces their financial stability index, and vice versa.

\section{The macroeconomic variables}

1. Real rate of economic growth (GRW). It is used to control for the macroeconomic cycle and its effects on the level of bank risk. Economic recession indicate a suffering condition for banks and thus increases the likelihood of bank insolvency, while an economic upswing will have the positive effect. Also banking system stability is considered a great incentive of future GDP growth, Durations of instability which followed by a decline in the real rate of economic growth.

2. Rate of inflation (INF). If rate of inflation has a negative impact on financial stability index, this explains the role of financial and economic policies of the government in backing the financial stability in the banking sector.

To identify the variables that affect the financial stability of the banking sector, we summarize a literature survey on stability measurement in the below table. 
Table 4.2: Studies of Stability measurement

\begin{tabular}{|c|c|c|c|}
\hline Authors & Dependent variables & Independent variables & Methods \\
\hline $\begin{array}{l}\text { İSKENDEROĞLU } \\
\text { \&TOMAK (2013) }\end{array}$ & $\begin{array}{l}\text { Z-index } \\
\text { (NPL's) the ratio } \\
\text { of Nonperforming } \\
\text { loans to total loans }\end{array}$ & $\begin{array}{l}\text { Asset Composition } \\
\text { Deposit Ratio } \\
\text { Bank Size } \\
\text { HHI Assets (HHTA) } \\
\text { HHI Deposits (HHD) } \\
\text { HHI Loans (HHL) }\end{array}$ & Panel data \\
\hline $\begin{array}{l}\text { Ghassan \&Taher } \\
\text { (2013) }\end{array}$ & Z-index & $\begin{array}{l}\text { Total Assets } \\
\text { Ratio of Loans to Assets } \\
\text { Operating costs to income } \\
\text { Income diversity } \\
\text { Share of Islamic Banks } \\
\text { Herfindahl index (LHHI) } \\
\text { Real economic growth rate } \\
\text { Inflation Rate } \\
\text { Dummy variables }\end{array}$ & Panel data \\
\hline $\begin{array}{l}\text { Čihák \& Hesse } \\
\text { (2008) }\end{array}$ & Z-index & $\begin{array}{l}\text { Ratio of Loans to Assets } \\
\text { operating costs to income } \\
\text { Assets } \\
\text { Income diversity } \\
\text { Herfindahl index (LHHI) } \\
\text { Share of Islamic Banks } \\
\text { Exchange Rate Depreciation } \\
\text { Inflation } \\
\text { Real GDP Growth } \\
\text { Governance } \\
\text { Dummy variables }\end{array}$ & Panel data \\
\hline $\begin{array}{l}\text { Boumediene and } \\
\text { Caby ( 2009) }\end{array}$ & Volatility & $\begin{array}{l}\text { Commercial Banks Return Ante } \\
\text { Commercial Banks Return Ante } \\
\text { Post } \\
\text { Islamic Banks Return Ante } \\
\text { Islamic Banks Return Post }\end{array}$ & $\begin{array}{l}\text { The EGARCHand } \\
\text { GJR- GARCH } \\
\text { Asymmetric Models }\end{array}$ \\
\hline
\end{tabular}




\begin{tabular}{|c|c|c|c|}
\hline Authors & Dependent variables & Independent variables & Methods \\
\hline $\begin{array}{l}\text { Beck, Kunt \& } \\
\text { Merrouche (2010) }\end{array}$ & $\begin{array}{l}\text { Z-index } \\
\text { Return on assets } \\
\text { Equity assets ratio }\end{array}$ & $\begin{array}{l}\text { Total Aassets } \\
\text { Non-loan earnings assets } \\
\ln (\text { GDP per capita) } \\
\text { Fixed assets } \\
\text { GDP growth } \\
\text { Concentration ratio } \\
\text { Financial freedom index } \\
\text { Private credit GDP ratio } \\
\text { Islamic bank dummy }\end{array}$ & Panel data \\
\hline $\begin{array}{l}\text { Altaee, Talo and } \\
\text { Adam (2013) in }\end{array}$ & Z-index & $\begin{array}{l}\text { Total Assets } \\
\text { Loans/Total Assets } \\
\text { Cost/Income } \\
\text { Income Diversity } \\
\text { GDP Growth. And Inflation } \\
\text { Banks Market Share } \\
\text { Governance } \\
\text { Dummy variable. }\end{array}$ & $\begin{array}{l}\text { Ordinary Least } \\
\text { Squares }\end{array}$ \\
\hline $\begin{array}{l}\text { ALI MIRZAEI } \\
(2010)\end{array}$ & $\begin{array}{l}\text { Profitability Indicator } \\
\text { Z-index }\end{array}$ & $\begin{array}{l}\text { Market share } \\
\text { Firm concentration ratio } \\
\text { Interest rate spread } \\
\text { Size of bank } \\
\text { Equity to total assets } \\
\text { Cost to income ratio } \\
\text { Liquid assets to total assets } \\
\text { Overheads to total assets } \\
\text { Off-balance-sheet activity } \\
\text { to total assets } \\
\text { Market growth (total assets) } \\
\text { Domestic credit provided } \\
\text { by banking system } \\
\text { Inflation and GDP growth }\end{array}$ & Panel data \\
\hline
\end{tabular}




\section{Chapter 5}

\section{EMPIRICAL RESULTS}

In this chapter, we start to measure the financial stability without separating the effect of the nature of Islamic banks for the effect of banking sector and macroeconomic factors. Then we turned to regression analysis, the panel data have been used.

Panel regression deals with multi-dimensional data that contained observations of measurements obtained over multiple time periods for the same firms. Also to know whether all variables are stationary, we conduct tests on panel data, this test is a Fisher- type unit-root test. Additionally, we conduct Hausman Test to see which model we should use, a fixed or rondom effect.

We have also prepared descriptive statistics and the correlation matrix to know whether there the multicollinearity problem, in the end, we analyzed with making some regression models by use fixed or random effect.

\subsection{Measuring Bank Stability}

By the numbers shown in the graph below can be summarized as follows; Small conventional banks are more stable than large conventional banks. Small Islamic banks more stable than large Islamic banks. And large conventional banks more stable than large Islamic banks. That is mean Conventional banks are more stable and sharia-compliant banks are less stable in banking sector operating in Turkey. 


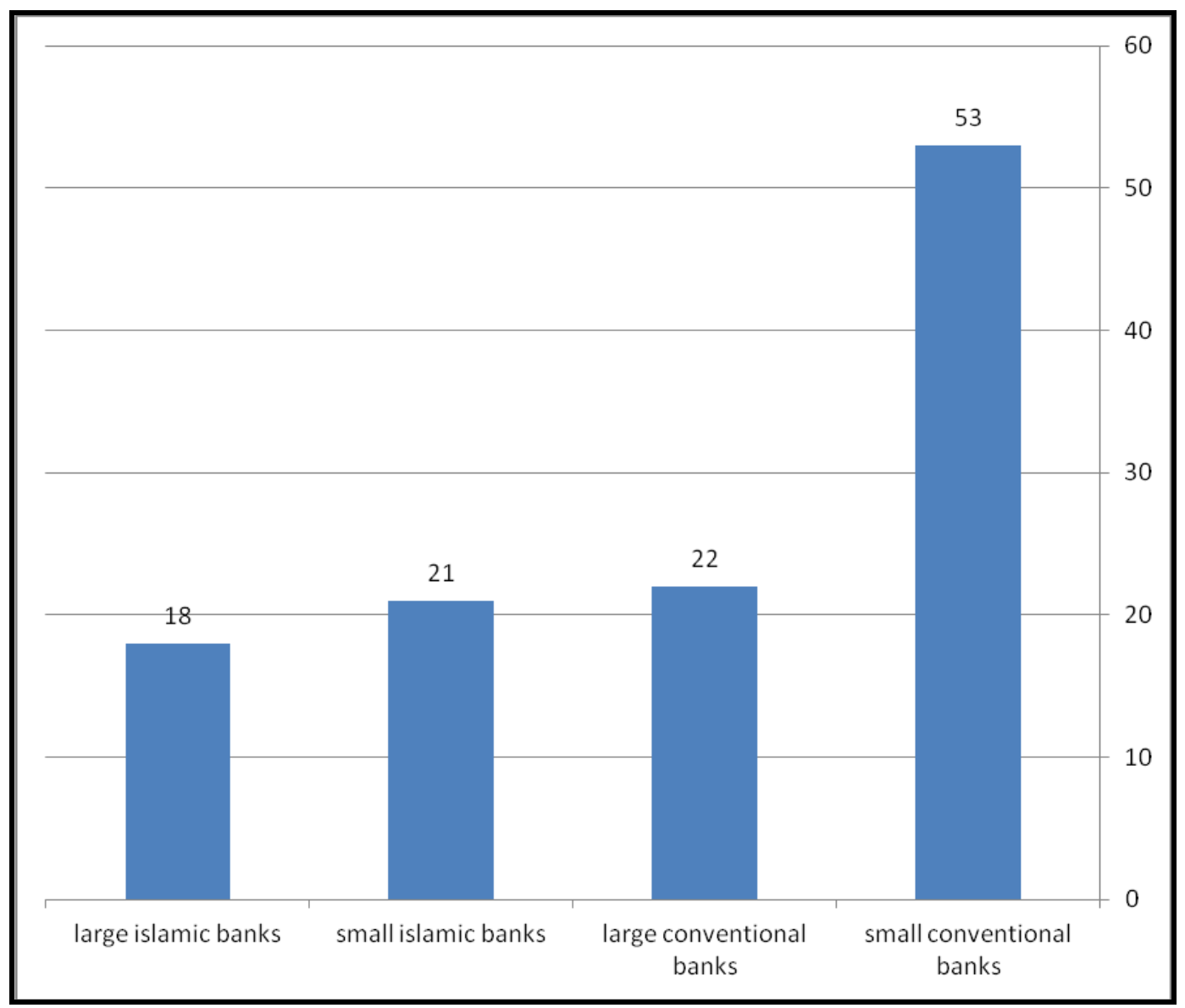

Figure 5.1: Comparison of average Z-scores to the banking sector operating in Turkey

\section{2 Regression analysis}

\subsubsection{Panel Unit Root Tests}

As a starting point of the analysis, this study applies Panel unit root test, which tend to exhibit a time trend and are therefore stationary; i.e., the variables in question have means, variances, and covariances that are time invariant. So as part of the thesis, we conducted tests on panel data [see appendix 1 to 8]. This test is a Fisher-type unitroot test, which works well with an unbalanced panel.

The Hypothesis:

Ho: All panels contain unit roots.

Ha: At least one panel is stationary. 
We found compelling evidence against the null hypothesis, and therefore conclude that all variables are stationary, except the log of Herfindahl index, so we dropped this variable from our regression model. That is mean the banking sector of Turkey have the competitive relationship is not clear, This is in line with the part of the literature on banking sector in Turkey such as İskenderoglu, And Tomak, 2013.

\subsubsection{Hausman Test}

As a second stage of the analysis. Our main objective is to find out the appropriate model to estimate results. In other words, Panel data models are usually estimated using either pooled ordinary least squares (OLS), fixed effects or random effects model. Therefore, we shall apply Hausman Test to find out the right model.

The Hypothesis:

Ho: Random effect model is appropriate.

Ha: Fixed effect model is appropriate.

Table 5. 1 represents the Result of Hausman test. Based on our test, we reject the null hypothesis ( $\mathrm{P}$-value less than 5\%) that is mean fixed -effects model is the most appropriate to our data.

Table 5. 1: the Result of Hausman test

\begin{tabular}{|l|l|}
\hline chi2 & 604.37 \\
\hline Prob > chi2 & 0.0000 \\
\hline
\end{tabular}

\subsubsection{Descriptive Statistics}

Table 5.2 shows the descriptive statistics for each dependent and independent variables used in this study for all Banks. Descriptive statistics include Mean, 
Median, Maximum and Minimum, as well as standard deviation and the total number of observations.

The mean of financial stability index for All banks is 3.2874. The median is 3.2188 , and. The financial stability index had a standard deviation of 0.7794 . This table indicates that the loans constitute more than $55 \%$ of the bank's total assets. The costs to net income ratio is $80 \%$, which is very high. Also income diversity ratio of $42 \%$ is considered low. Furthermore, The market share of Islamic Bank is $4 \%$, which is very low.

Table 5.2: Descriptive Statistics for all Banks

\begin{tabular}{|c|c|c|c|c|c|c|c|c|c|}
\hline & LZSCOR & LAST & RCA & RCI & IDV & SHIB & GRW & INF & IBD \\
\hline Mean & 3.2874 & 8.8459 & .556 & .8097 & 0.412 & .0420 & .0395 & 0.0579 & 0.166 \\
\hline Median & 3.2188 & 9.0812 & 0.61 & 0.81 & 0.4 & .0418 & 0.435 & 0.07 & 0 \\
\hline Maximum & 5.1298 & 11.500 & 0.89 & 1.1 & 0.99 & .0553 & .092 & 0.1 & 1 \\
\hline Minimum & 0.6931 & 3.1354 & 0 & 0.10 & 0 & .0275 & -.048 & 0.01 & 0 \\
\hline Std. Dev. & 0.7794 & 1.9765 & 0.206 & .1323 & 0.176 & .8524 & .0435 & .0299 & 0.373 \\
\hline Obser. & 189 & 189 & 189 & 189 & 189 & 192 & 192 & 192 & 192 \\
\hline
\end{tabular}

We found that the descriptive statistics make sure the result of comparison of average Z-scores to the banking sector operating in Turkey, conventional banks are the most stable and Islamic banks are less stable in banking sector in Turkey. Where the table 5.3 tells us that the mean and the median of the conventional banks are 3.3634 and 3.2958, respectively. While the mean and the median of the Islamic banks are 2.91458 and 2.9444, respectively. 
Table 5.3: Descriptive Statistics of L Z-SCORE for Islamic and Conventional Banks

\begin{tabular}{|c|c|c|c|}
\hline & Islamic Banks & Conventional Banks & All Banks \\
\hline Mean & 2.91458 & 3.3634 & 3.2874 \\
\hline Median & 2.9444 & 3.2958 & 3.2188 \\
\hline Maximum & 3.737 & 5.1298 & 5.1298 \\
\hline Minimum & 1.945 & 0.6931 & 0.6931 \\
\hline Std. Dev. & 0.35418 & 0.8203 & 0.7794 \\
\hline Obser. & 32 & 157 & 189 \\
\hline
\end{tabular}

In order measuring the variability. Theoretically, The standard deviation is best viewed as the average distance that individual data points are from the mean. Conventional Banks have higher standard deviations than Islamic Banks. Results for the Conventional banks sample show with a standard deviation of 0.8203 a significantly wider dispersion than results for Islamic banks sample with a standard deviation of 0.3541 . This may at least in part be caused by Islamic banks' lower sample size.

\subsubsection{Correlation Matrix}

This Matrix is a table that contains coefficients of correlation among many variables in different timeframes. Table 5.4 shows cross correlation matrix of variables. This Analysis is applied to anticipate how independent variables will be correlated with Z-SCOR indicator.

Another objective of Correlation Analysis is to find out if the independent variables have high correlation with each other or no, in other words, to examine for multicollinearity problem. 
Table 5.4: Correlation Matrix

\begin{tabular}{|c|c|c|c|c|c|c|c|c|c|}
\hline & LZSCOR & LAST & RCA & RCI & IDV & SHIB & GRW & INF & IBD \\
\hline LZSCOR & 1 & & & & & & & & \\
\hline LAST & -0.0268 & 1 & & & & & & & \\
\hline RCA & 0.259 & 0.449 & 1 & & & & & & \\
\hline RCI & 0.606 & -0.152 & 0.270 & 1 & & & & & \\
\hline IDV & -0.270 & 0.054 & 0.080 & -0.217 & 1 & & & & \\
\hline SHIB & 0.261 & 0.128 & 0.138 & 0.033 & -0.149 & 1 & & & \\
\hline GRW & 0.030 & -0.004 & 0.045 & -0.041 & 0.2912 & -0.054 & 1 & & \\
\hline INF & -0.192 & -0.042 & -0.038 & -0.035 & 0.1292 & -0.344 & -0.04 & 1 & \\
\hline IBD & -0.216 & -0.039 & 0.462 & -0.041 & 0.1092 & 0.075 & 0.002 & 0.037 & 1 \\
\hline
\end{tabular}

Before starting the analysis, we must take into account two things, firstly, sign of correlation, positive or negative correlation between two variables. Secondly, size of correlation, Equal to 1, means perfectly linear relationship between two variables, close to one, means stronger linear relationship between two variables, and close to zero, means weaker linear relationship between two variables.

We found that the correlation matrix make sure the result of comparison of average z-scores to the banking sector operating in Turkey, conventional banks are the most stable and Islamic banks are less stable in banking sector in Turkey. Where the Islamic dummy variable is anticipated to hold a negative correlation signal denote a fragility in the financial system of related banks set, while holding a positive sign denote the strength in the financial system of the related banks set and its support to the stability of the banking sector.

We found the dummy variable taken negative correlation sign in the correlation matrix. Our analysis indicates that conventional banks fared differently than did 
Islamic banks during the study period, which requires the increased attention to find out the reasons behind this the weak role of the Islamic banks compare to the conventional banks in Turkey. In addition, we concluded from the previous table that the independent variables are not highly correlated with Z-SCORE indicate, also the independent variables do not have a high correlation with each other, in other words, there are not multicollinearity problem. Where the correlations in Table 5.4 suggest that the financial stability index has a weak negative correlation with the log of total assets, Income diversity and the inflation rate. Also the financial stability index has a positive moderate correlation with The cost-to-income ratio. In addition, the financial stability index has a weak positive correlation with the loan to assets ratio, and the market share of Islamic banks. Lastly, the financial stability index has a possible positive correlation with Real rate of economic growth.

Also, we found interesting correlations between some bank independent variables. For instance, there is a possible correlation between the Real rate of economic growth with the Islamic dummy variable and the inflation rate.

\subsubsection{The regression results}

As we know in order conducted empirical analysis the panel data has been used on The bank specific variables, the banking sector variables, and the macro-economic variables. We analyzed with making some models by use fixed effect model. In our study, we also evaluate the robustness of the results with regard to the sample selected. In order to do so, we make the four regressions for different variables with fixed-effect model [see Table 5.5]. Precisely, we estimate the regressions separately for sub-samples of variables and for all variables. 
The regression results for the factors associated with the z-score appear in Table 5.5, except, the log of Herfindahl index is non stationary, so we dropped this variable from our regression model.

Logarithm of total assets (LAST) has a significant negative sign in the regressions for banks at the level of the 1 percent (see Table 5.5, Model 1, 2, and 3). The negative relationship between z-core index and the Bank Size means that a larger banks operating in Turkey tend to have lower z-scores, perhaps because they engage in riskier activities than smaller banks and reflecting a relatively higher risk aversion of small banks. Our findings suggest that turkish banks to be more stable, needs to drive to be a smaller. But taking into account that the small banks may be more risky because of the reducing ability to diversify their sources of income, in all spectrums including geographic, customer and industry.

Credit or loan to assets ratios (RCA) or finance to assets ratios for all banks have the expected sign. A significant negative sign at the level of 1 percent and 5 percent in the regressions for banks (see Table 5.5, Model 1 and 2). This slope coefficient is negative, it confirmed that bank stability decreased with increase in loan to asset ratio. In other words, The Banks which have high loan to asset ratios move toward low index of financial stability.

Banks with higher loan portfolios on their balance sheets relative to their total assets might be more likely to experience problems with non-performing loans and thus be riskier. Furthermore, the rapid growth in credit is strongly associated with financial instability and the risk of financial crisis. 
Table 5.5: Regression results - fixed Effects

\begin{tabular}{|c|c|c|c|c|c|c|}
\hline \multicolumn{2}{|c|}{$\begin{array}{c}\text { Independent } \\
\text { Variables }\end{array}$} & $\begin{array}{c}\text { Expected } \\
\text { Sign }\end{array}$ & $\begin{array}{l}\text { Model } \\
1\end{array}$ & $\begin{array}{c}\text { Model } \\
2\end{array}$ & $\begin{array}{c}\text { Model } \\
3\end{array}$ & $\begin{array}{c}\text { Model } \\
4\end{array}$ \\
\hline 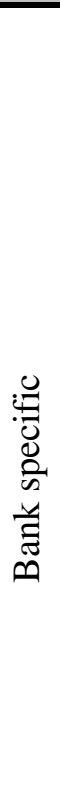 & RCA & + & $\begin{array}{l}-.3679019 \\
(-2.78)^{* * *} \\
-1.460175 \\
(-3.09)^{* * *} \\
1.244367 \\
(3.59)^{* * *} \\
-.8982319 \\
(-3.81)^{* * *} \\
(\text { Omitted) }\end{array}$ & $\begin{array}{l}-.2884159 \\
(-2.13)^{* *} \\
-1.112428 \\
(-2.28)^{* *} \\
1.210379 \\
(3.32)^{* * *} \\
-.6047444 \\
(-2.73)^{* * *} \\
(\text { Omitted })\end{array}$ & $\begin{array}{c}-.2704677 \\
(-2.84)^{* * *} \\
-.0994613 \\
(-0.21) \\
1.879996 \\
(5.08)^{* * *} \\
-.7277437 \\
(-2.78)^{* * *} \\
(\text { Omitted) }\end{array}$ & \\
\hline 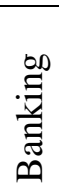 & SHIB & + & $\begin{array}{l}.364109 \\
(6.33)^{* * *}\end{array}$ & $\begin{array}{l}.3521151 \\
(6.10)^{* * *}\end{array}$ & & $\begin{array}{l}.2259689 \\
(6.16)^{* * *}\end{array}$ \\
\hline 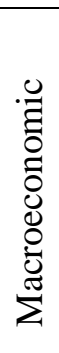 & GRW & + & $\begin{array}{c}2.456728 \\
(3.63) * * * \\
-1.768176 \\
(-1.87)\end{array}$ & & $\begin{array}{c}1.605059 \\
(2.17)^{* *} \\
-3.219094 \\
(-3.14)^{* * *}\end{array}$ & $\begin{array}{c}.77908 \\
(1.17) \\
-2.62859 \\
(0.012)^{* *}\end{array}$ \\
\hline & rations & & 189 & 189 & 189 & 189 \\
\hline & uared & & 0.4385 & 0.3717 & 0.2959 & 0.2813 \\
\hline
\end{tabular}

T-values in brackets:

*** significant at $1 \%$.

** significant at $5 \%$.

* significant at $10 \%$. 
The cost-to-income ratios (RCI) for banks does not have the expected sign. They have a positive significant sign in the regressions for banks at the level of 1 percent (see Table 5.5, Model 1, 2, and3). So, This result inconsistent with the fact that a ratios of costs to income have an almost negative role in improving the index of financial stability (e.g., Čihák and Hesse 2008, and Mirzaei, 2010).

Greater operating cost to income ratios lead to deteriorate financial stability index. This ratio is used as a measure shows how banks operating in Turkey manage their total costs relative to their income, the higher this ratio refers the inefficiency. Inefficient banks in terms of their cost-to-income ratio are less likely to cover their costs when hit by adverse shocks, so they tend to be riskier.

Income diversity (IDV) has a significant negative sign in the regressions for banks at the levels of 1 percent (see Table 5.5, Model 1, 2, and 3) and does not consistent with the expected sign. This is in line with the part of the literature on banking sector (e.g., Altaee, and Adam, 2013).

The ratio of Income diversity can range from zero to one. One means, the total operating income of a bank is divided equally between net interest income and other operating income. Zero means, there is no diversification and a bank depends on a few sources to generate the total operating income. In other words, a weak income diversity leads to decrease financial stability in banks operating in Turkey, and reflects the simple support to the financial stability index in the banking system in Turkey via the diversification of financial products. 
Also, This might be interpreted as the banks in turkey become more stable by specialization. They can generate more income across time from a few sources that increases the return on assets resulting an increase in the stability of the banks. This illustrates that turkish banks depend on lending-based operation instead a move to other income sources in order increase financial stability to these banks. Because when income diversification leads to diversify the risk associated with this income, thus mitigating the effects of these risks.

A number of studies propose that as banks move away from their traditional lending activities (those generating interest income) and diversify their product mix, they will be less subject to economic cycles associated with loan portfolios.

Regarding the impact of a higher presence of Islamic banks on banking stability, the slope coefficient of the "share of Islamic banks" variable is positive and significant in all (see Table 5.5, Models 1, 2, and 4). Based on this estimated slope coefficient, we can say that a higher share of Islamic banks increases financial stability in the Turkish banking system. That is mean banks operating in Turkey with higher Islamic bank share have contributed effectively to improve the stability of banking sector by diversifying in their assets.

The positive sign of correlation between the Islamic banks' market share and the Islamic bank dummy would indicate that a higher share of Islamic banks increases their soundness, which means increases their financial stability index, and vice versa.

Regarding the macroeconomic variables, Real rate of economic growth (GRW). It is used to control for the macroeconomic cycle and its effects on the level of bank risk. 
Economic recession indicate a suffering condition for banks and thus increases the likelihood of bank insolvency, while an economic upswing will have the positive effect. Also banking system stability is considered a great incentive of future GDP growth, Durations of instability which followed by a decline in the real rate of economic growth

We found Real GDP growth appears to have a positive and significant impact on the financial stability of the banking system in the regressions for banks operating in Turkey at the level of 1 percent and 5 percent (see Table 5.5, Model 1and 3). that denote a the strength of the Turkish macroeconomy. also reflects the ability of the economy to create wealth.

The inflation rate is measuring the rate of increase of various price indices, has a negative and significant effect on financial stability indicator at the levels of 1 percent and 5 percent in the regressions for banks (see Table 5.5, Model 3, and 4), Inflation indicate there are structural problems in the economy, or public dissatisfaction which may in turn lead to instability. As the inflation increases, people need more money for they consumptions and expenditures, hence affecting their total saving and deposits negatively.

High levels of inflation would signal structural weakness in the economy and increased levels of indebtedness, potentially leading to a tightening of monetary conditions. Conversely, low levels of inflation could potentially increase the risk appetite in the financial markets. 
Finally, the two macroeconomic variables explain the important role of the government through the financial and economic policies in increase the financial stability of the banks operating in Turkey. 


\section{Chapter 6}

\section{CONCLUSION}

This study investigated the financial stability of Islamic banks relative to conventional banks operating in Turkey. Through the use of Z-index as a measure of financial stability. We found that conventional banks are the most stable and Islamic banks are less stable in banking sector operating in Turkey, where small commercial banks have financial stability more than large commercial banks, large commercial banks have financial stability more than large Islamic banks, and small Islamic banks appear to have financial stability more than large Islamic banks.

The findings also indicate there a negative relationship between the size of the bank and financial stability. Banks which have high loan to asset ratios moves toward low index of financial stability. The cost-to-income ratios has a significant positive sign, This result inconsistent with the fact that a ratio of costs to income have an almost negative role in improving the index of financial stability. Greater operating cost to income ratios lead to deteriorate financial stability index, where this ratio is used as a measure shows how banks operating in Turkey manage their total costs relative to their income, this ratio refers the inefficiency. And income diversity leads to decrease financial stability in banks operating in Turkey, and reflects the simple support to the financial stability in the banking sector in Turkey via the diversification of financial products. This illustrates that turkish banks depend on lending-based operation instead a move to other income sources in order increase 
financial stability to these banks. We found also that banks operating in Turkey with higher Islamic bank share have contributed effectively to improve the financial stability by diversifying in their assets. Regarding the macroeconomic variables (GDP, inflation) have significant effects on stability, which explains the importance role of the government through the financial and economic policies in increase the financial stability of the banks operating in Turkey. Lastly. I hope that our empirical findings encourage more studies in this area. 


\section{REFERENCES}

[1] Adel Ahmed, (2010). Global Financial Crisis: An Islamic Finance Perspective. International Journal of Islamic and Middle Eastern Finance and Management. Vol. 3 (4). PP.306 - 320.

[2] Ali Said, 2012. Efficiency in Islamic Banking during a Financial Crisis-an Empirical Analysis of Forty-Seven Banks. Journal of Applied Finance and Banking. Vol.2, no.3. P 164.

[3] AlKholi, H. (2009). Impact of Financial Crisis on Banking Sector. [Online] Available from: http://www.iifef.org/node/1154 [Accessed 4th March 2013].

[4] Altaee,H.,Talo,I.and Adam,M .(2013). Testing the Financial Stability of Banks in GCC Countries: Pre and Post Financial Crisis. International Journal of Business and Social Research. Vol. 3. No. 4.

[5] Ariss, R. (2010). Competitive conditions in Islamic and conventional banking: A global perspective. Review of Financial Economics. Vol. 19.PP. 101108.

[6] Babecky, J. Komarek, L. Komárková, Z. (2010). Financial integration at times of financial instability. Czech Journal of Economics and Finance. Vol. 63.No. 1. P. 26 
[7] Bader ,M.and Mohamad, S. And Ariff, M. And Hassan, T. (2008). Cost, revenue, and profit efficiency of Islamic versus conventional banks: international evidence using data envelopment analysis. Islamic Economic Studies, Vol. 15, No. 2, January 2008, 23-76.

[8] Bashir, A. H. M. (2001). Assessing the Performance of Islamic Banks: Some Evidence from the Middle East. Middle Eastern and North African Economies, electronic journal. Vol. 3. Middle East Economic Association and Loyola University Chicago. Sep 2001. http://www.luc.edu/orgs/meea/

[9] Beck, T. Kant, A. D., \& Merrouche, O. (2010). Islamic vs. Conventional Banking: Business Model. Efficiency and Stability. World Bank Policy Research Working Paper No. 5446.__ Retrieved from: http://papers.ssrn.com/sol3/papers.cfm?abstract_id=1694335

[10] Boumediene, A. and Caby, J. (2009). The stability of Islamic banks during the subprime crisis. Available at SSRN. http://ssrn.com/abstract=1524775

[11] Čihák, M And Hesse, H. (2008). Islamic Banks and Financial Stability. IMF Working Papers 08/16. International Monetary Fund. P 4

[12] Čihák, M., \& Hesse, H. (2008). Islamic Banks and Financial Stability: An Empirical Analysis. IMF Working Paper No. 08/16. Washington: International Monetary Fund. 
[13] Dobravolskas, A. Seiranov, J. (2011). Financial Stability as the Goal of PostCrisis Regulatory Reforms. Business Systems and Economics. № 1. 2011. PP. 101-114. ISSN 2029.8234 (online).

[14] Ghassan, B. and Taher, B. (2013). Financial Stability of Islamic and Conventional Banks in Saudi Arabia: Evidence using Pooled and Panel Models. MPRA Paper 54472. University Library of Munich, Germany. P 2.

[15] Greening, V. And Iqbal, Z. (2008). Risk Analysis for Islamic Banks. Washington. DC. The world bank Group. P 2

[16] Hasan, M. And Dridi, J. (2010). The Effects of the Global Crisis on Islamic and Conventional Banks: A Comparative Study. IMF Working Paper 010/201. International Monetary Fund.

[17] Hasan, M., \& Dridi, J. (2010). The Effects of the Global Crisis on Islamic and Conventional Banks: A Comparative Study. IMF Working Paper Series. Retrieved from: www.imf.org/external/pubs/ft/wp/2010/wp10201.pdf

[18] Hussein, K. (2010). Bank-level stability factors and consumer confidence - A comparative study of Islamic and conventional banks'product mix. Journal of Financial Services Marketing Vol.15.PP 259-270.

[19] Imam, P. And Kpodar, K. (2010). Islamic Banking: How it is diffused? International Monetary Fund Working Paper 10.195. 
[20] Iqbal, Z., and A. Mirakhor. 2011. An Introduction to Islamic Finance: Theory and Practice. Singapore: John Wiley and Sons (Asia). PP 75-77.

[21] İskenderoğlu, O. And Tomak, S. (2013). Competition and Stability: An Analysis of the Turkish Banking System. International Journal of Economics and Financial Issues. Vol. 3. No. 3. PP.752-762.

[22] Javaid, S. And Anwar, J. And Zaman, K. And Gafoor, A. (2011). Determinants of Bank Profitability in Pakistan: Internal Factor Analysis. Mediterranean Journal of Social Sciences. Vol. 2. No. 1. ISSN 2039-2117.

[23] Kaleem, A. (2000). Modelling Monetary Stability under Dual Banking System: The Case of Malaysia. International Journal of Islamic Financial Services. Vol. 2. No.1

[24] Mirzaei. A (2010). The Effect of Market Power on Stability and Performance of Islamic and Conventional Banks. Islamic Economic Studies. Vol. 18. No. 1.

[25] Moin, M. (2013). Financial Performance of Islamic Banking and Conventional Banking in Pakistan: A Comparative Study. International Journal of Innovative and Applied Finance. http://cls.irp.edu.pk/index.php/ijiaf/editor/issueToc/19

[26] Othman, J. (2012). Analyzing Financial Distress in Malaysian Islamic Banks: Exploring Integrative Predictive Methods. Thesis of doctoral. Durham University. United Kingdom. 
[27] Ouerghi, F. (2014). Are Islamic Banks More Resilıent To Global Financial Crısıs Than Conventıonal Banks?. Asian Economic and Financial Review. Vol. 4. No.7. PP 941-955

[28] Participation Banks Association of Turkey http://www.tkbb.org.tr.

[29] Rahim, S. Zakaria, R (2013). Comparison on Stability Between Islamic and Conventional Banks in Malaysia. Journal of Islamic Economics, Banking and Finance, Vol. 9 No. 3.

[30] Said,P. (2008). Islamic Alternatives to Conventional Finance. In R. Millar and H. Anwar (Eds.), Islamic Finance: A Guide for International Business and Investment. London: GMB Publishing Ltd.

[31] The Banks Association of Turkey http://www.tbb.org.tr.

[32] Ust $\mathrm{Hj}$ Zaharuddin $\mathrm{Hj}$ Abed Rahman, Differences between Islamic and Conventional Banks, Senarai Lengkap Artikel, http://zaharuddin.net/index.php?option=com_content\&task=view\&id=297\&Itemid =72, Thursday, 22 February 2007 18:02, 1. 
APPENDICES 


\section{Fisher-type: Unit Root Test}

The null hypothesis of this test is that all panels contain a unit root. So we reject this hypothesis. If we look at our tests $\mathrm{P}, \mathrm{Z}, \mathrm{L}^{*}$ and $\mathrm{Pm}$, we get a value for these test statistics, and in the next column you see the p-value. Since they are all smaller than 0.01 , we can reject the null hypothesis at the $1 \%$ level of statistical significance. This means there are no unit roots in your panels under the given test conditions (included panel mean and time trend). Here we found overwhelming evidence against the null hypothesis of a unit root. Therefore, conclude that all variables are stationary.

Appendix 1: Unit Root Test for LZ-SCORE

\begin{tabular}{|c|c|}
\hline \multicolumn{2}{|l|}{$\begin{array}{l}\text { Fisher-type unit-root test for lzscor } \\
\text { Based on augmented Dickey-Fuller tests }\end{array}$} \\
\hline $\begin{array}{l}\text { Ho: All panels contain unit roots } \\
\text { Ha: At least one panel is stationary } \\
\text { AR parameter: Panel-specific } \\
\text { Panel means: Included } \\
\text { Time trend: Not included } \\
\text { Drift term: Not included }\end{array}$ & $\begin{array}{llr}\text { Number of panels } & = & 24 \\
\text { Avg. number of periods }= & 7.88 \\
\text { Asymptotics: } T->\text { Infinity }\end{array}$ \\
\hline statistic & p-value \\
\hline $\begin{array}{ll}\text { Inverse chi-squared (48) } & P \\
\text { Inverse normal } & \mathrm{Z} \\
\text { Inverse logit } t(124) & L^{*} \\
\text { Modified inv. chi-squared } & \text { Pm }\end{array}$ & $\begin{array}{l}0.0000 \\
0.0002 \\
0.0001 \\
0.0000\end{array}$ \\
\hline $\begin{array}{l}\text { P statistic requires number of panels to be } \\
\text { Other statistics are suitable for finite or }\end{array}$ & $\begin{array}{l}\text { e finite. } \\
\text { r infinite number of panels. }\end{array}$ \\
\hline
\end{tabular}

Appendix 2: Unit Root Test for LAST

\begin{tabular}{|c|c|}
\hline \multicolumn{2}{|l|}{$\begin{array}{l}\text { Fisher-type unit-root test for last } \\
\text { Based on augmented Dickey-Fuller tests }\end{array}$} \\
\hline $\begin{array}{l}\text { Ho: All panels contain unit roots } \\
\text { Ha: At least one panel is stationars } \\
\text { AR parameter: Panel-specific } \\
\text { Panel means: Included } \\
\text { Time trend: Not included } \\
\text { Drift term: Not included }\end{array}$ & $\begin{array}{l}\text { Number of panels }=r \\
\text { Avg. number of periods }=\end{array}$ \\
\hline statistic & $p$-value \\
\hline $\begin{array}{ll}\text { Inverse chi-squared (48) } & P \\
\text { Inverse normal } & \mathrm{Z} \\
\text { Inverse logit t(124) } & \mathrm{L}^{*} \\
\text { Modified inv. chi-squared } & \mathrm{Pm}\end{array}$ & $\begin{array}{l}0.0000 \\
0.0087 \\
0.0000 \\
0.0000\end{array}$ \\
\hline $\begin{array}{l}\text { P statistic requires number of panels to be } \\
\text { other statistics are suitable for finite or }\end{array}$ & $\begin{array}{l}\text { finite. } \\
\text { infinite number of panels. }\end{array}$ \\
\hline
\end{tabular}


Appendix 3: Unit Root Test for RCA

Fisher-type unit-root test for rca

Based on augmented Dickey-Fuller tests

Ho: All panels contain unit roots

Ha: At least one panel is stationary

Number of panels $=24$

Avg. number of periods $=7.88$

AR parameter: Panel-specific

Asymptotics: T $\rightarrow$ Infinity

Panel means: Included

Time trend: Not included

Drift term: Not included

ADF regressions: 0 lags

\begin{tabular}{llrr} 
& & Statistic & $\mathrm{p}$-value \\
\hline Inverse chi-squared(48) & $\mathrm{P}$ & 95.4966 & 0.0001 \\
Inverse normal & $\mathrm{Z}$ & -1.4278 & 0.0767 \\
Inverse logit $t(119)$ & $\mathrm{L}^{*}$ & -2.2591 & 0.0128 \\
Modified inv. chi-squared & $\mathrm{Pm}$ & 4.8476 & 0.0000 \\
\hline
\end{tabular}

$P$ statistic requires number of panels to be finite.

Other statistics are suitable for finite or infinite number of panels.

Appendix 4: Unit Root Test for RCI

Fisher-type unit-root test for rci

Based on augmented Dickey-Fuller tests

Ho: All panels contain unit roots

Ha: At least one panel is stationary

Number of panels $\quad=24$

Avg. number of periods $=7.88$

AR parameter: Panel-specific

Panel means: Included

Asymptotics: T -> Infinity

Time trend: Not included

Drift term:

ADF regressions: 0 lags

\begin{tabular}{llrr}
\hline & & Statistic & p-value \\
\hline Inverse chi-squared(48) & $\mathrm{P}$ & 108.8009 & 0.0000 \\
Inverse normal & $\mathrm{Z}$ & -3.0140 & 0.0013 \\
Inverse logit t(124) & $\mathrm{L}^{*}$ & -3.8769 & 0.0001 \\
Modified inv. chi-squared & $\mathrm{Pm}$ & 6.2055 & 0.0000 \\
\hline
\end{tabular}

$P$ statistic requires number of panels to be finite.

Other statistics are suitable for finite or infinite number of panels.

Appendix 5: Unit Root Test for IDV

Fisher-type unit-root test for idv

Based on augmented Dickey-Fuller tests

Ho: All panels contain unit roots

Number of panels $=24$

Ha: At least one panel is stationary

Avg. number of periods $=7.88$

AR parameter: Panel-specific

Asymptotics: T $\rightarrow$ Infinity

Panel means: Included

Time trend: Not included

Drift term: Not included

ADF regressions: 0 lags

\begin{tabular}{llrr} 
& & Statistic & p-value \\
\hline Inverse chi-squared(48) & $\mathrm{P}$ & 381.8609 & 0.0000 \\
Inverse normal & $\mathrm{Z}$ & -12.5680 & 0.0000 \\
Inverse logit t(124) & $\mathrm{L}^{*}$ & -21.0536 & 0.0000 \\
Modified inv. chi-squared $\mathrm{Pm}$ & 34.0745 & 0.0000
\end{tabular}

$P$ statistic requires number of panels to be finite.

Other statistics are suitable for finite or infinite number of panels. 
Appendix 6: Unit Root Test for SHIB

\begin{tabular}{|c|c|}
\hline \multicolumn{2}{|l|}{$\begin{array}{l}\text { Fisher-type unit-root test for shib } \\
\text { Based on augmented Dickey-Fuller tests }\end{array}$} \\
\hline $\begin{array}{l}\text { Ho: All panels contain unit roots } \\
\text { Ha: At least one panel is stationary } \\
\text { AR parameter: Panel-specific } \\
\text { Panel means: Included } \\
\text { Time trend: Included } \\
\text { Drift term: Not included }\end{array}$ & $\begin{array}{lr}\text { Number of panels }= & 24 \\
\text { Number of periods }= & 8 \\
\text { Asymptotics: T }->\text { Infinity }\end{array}$ \\
\hline Statistic & p-value \\
\hline $\begin{array}{ll}\text { Inverse chi-squared (48) } & \mathrm{P} \\
\text { Inverse normal } & \mathrm{Z} \\
\text { Inverse logit } \mathrm{t}(124) & \mathrm{L}^{\star} \\
\text { Modified inv. chi-squared } & \mathrm{Pm}\end{array}$ & $\begin{array}{l}0.0000 \\
0.0000 \\
0.0000 \\
0.0000\end{array}$ \\
\hline $\begin{array}{l}\text { P statistic requires number of panels to b } \\
\text { Other statistics are suitable for finite o }\end{array}$ & $\begin{array}{l}\text { e finite. } \\
r \text { infinite number of panels. }\end{array}$ \\
\hline
\end{tabular}

\section{Appendix 7: Unit Root Test for GRW}

Fisher-type unit-root test for grw

Based on augmented Dickey-Fuller tests

Ho: All panels contain unit roots

Ha: At least one panel is stationary

Number of panels $=24$

AR parameter: Panel-specific

Panel means: Included

Time trend: Not included

Drift term: Not included

Number of periods $=8$

Asymptotics: $T->$ Infinity

ADF regressions: 0 lags

\begin{tabular}{llrr} 
& & Statistic & p-value \\
\hline Inverse chi-squared(48) & $\mathrm{P}$ & 87.6280 & 0.0004 \\
Inverse normal & $\mathrm{Z}$ & -4.8493 & 0.0000 \\
Inverse logit t(124) & $\mathrm{L} *$ & -4.4745 & 0.0000 \\
Modified inv. chi-squared & $\mathrm{Pm}$ & 4.0445 & 0.0000 \\
\hline
\end{tabular}

$P$ statistic requires number of panels to be finite.

Other statistics are suitable for finite or infinite number of panels.

Appendix 8: Unit Root Test for INF

Fisher-type unit-root test for inf

Based on augmented Dickey-Fuller tests

Ho: All panels contain unit roots

Ha: At least one panel is stationary

Number of panels $=24$

AR parameter: Panel-specific

Number of periods $=8$

Panel means: Included

Asymptotics: T $->$ Infinity

Time trend: Not included

Drift term: Not included

ADF regressions: 0 lags

\begin{tabular}{llrr} 
& & Statistic & p-value \\
\hline Inverse chi-squared (48) & $\mathrm{P}$ & 158.4485 & 0.0000 \\
Inverse normal & $\mathrm{Z}$ & -8.6806 & 0.0000 \\
Inverse logit t(124) & $\mathrm{L} *$ & -8.8136 & 0.0000 \\
Modified inv. chi-squared & $\mathrm{Pm}$ & 11.2726 & 0.0000
\end{tabular}

$P$ statistic requires number of panels to be finite

Other statistics are suitable for finite or infinite number of panels. 
Appendix 9: Hausman Test

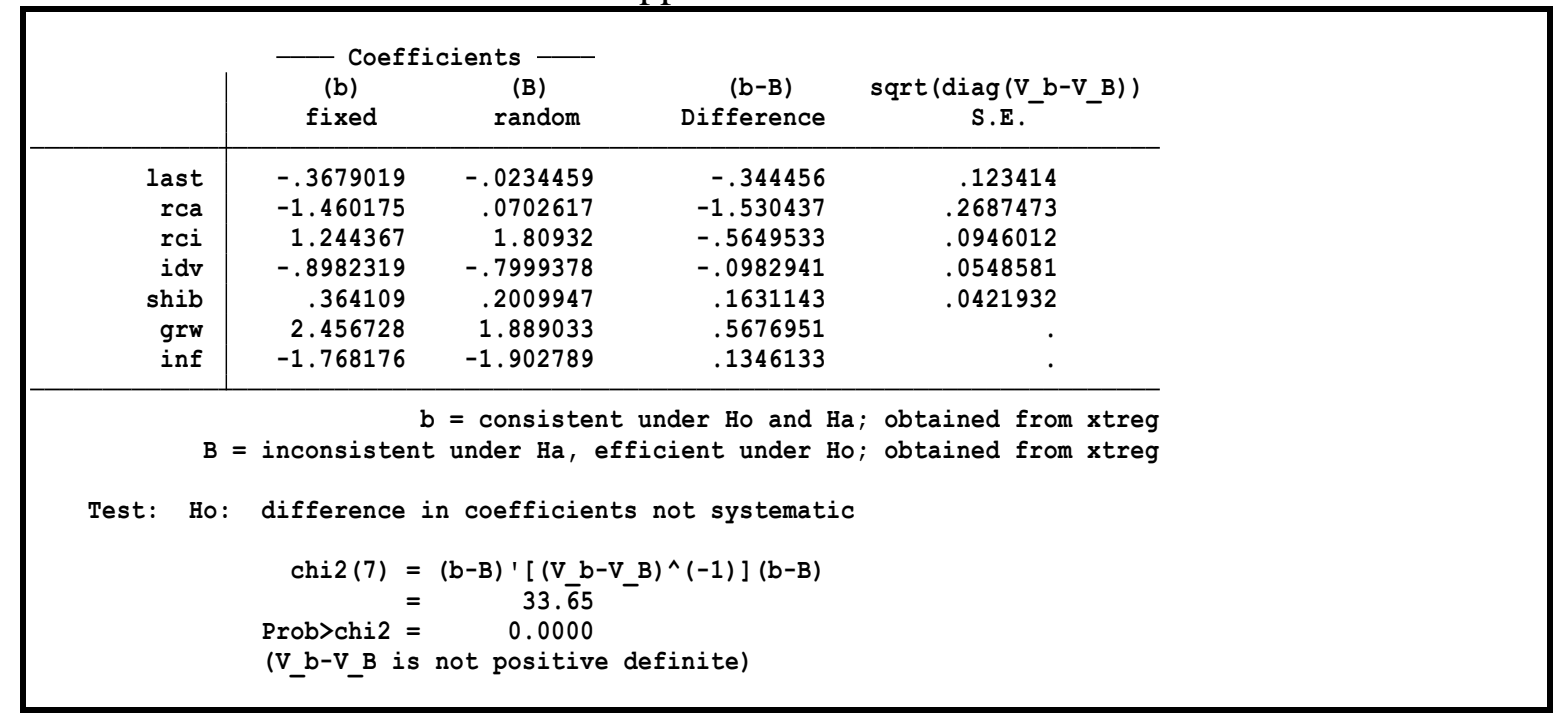

